\title{
In depth dynamic characterisation of French PDO Cantal cheese made from raw milk
}

\author{
Isabelle DE FREITAS ${ }^{a *}$, Nicolas PINONa, Anne THIERRY ${ }^{b}$, Christelle LOPEZ ${ }^{b}$, \\ Jean-Louis MAUBOIS ${ }^{b}$, Sylvie LORTAL ${ }^{b}$ \\ a Les Fromageries Occitanes (LFO), Borde Blanche - Zone Industrielle, \\ 31290 Villefranche de Lauragais, France \\ b UMR1253 Science et Technologie du Lait et de l'Euf, Inra-Agrocampus Rennes, \\ 65 rue de St-Brieuc, 35042 Rennes cedex, France
}

(Received 3 February 2007 - Accepted 6 March 2007)

\begin{abstract}
Cantal is the third French Protected Denomination of Origin cheese. The Cantal cheesemaking process is similar to Cheddar cheese. Both processes involve a milling and a dry salting step which results in a homogeneous salted curd. In order to determine the key parameters of the manufacturing process acting on the specific characteristics of this cheese variety, an extensive and kinetic study repeated three times was carried out at nine stages from the raw milk to $120 \mathrm{~d}$ ripened cheese. The microbial ecosystem was explored by numeration and by direct extraction of DNA and PCR-Temporal Temperature Gradient Electrophoresis. Lysis of the lactic acid bacteria was checked by quantification of the intracellular lactate dehydrogenase activity. Carbon sources changes, solubilisation of minerals, proteolysis, lipolysis, and formation of neutral volatile compounds were also assessed. Cheese microstructure modifications and bacterial localisation were determined by confocal scanning laser microscopy. The controlled manufacturing conditions and the use of a complex mixture of starters led to very similar ripened cheeses. The compositional attributes (in particular total solids, fat, nitrogen forms), the lipolysis $(0.7 \pm 0.2 \%$ fat $)$ and proteolysis final extent (34.4 $\mathrm{g} \cdot \mathrm{kg}^{-1}$ free amino acids in juice) were similar as well as major neutral volatiles compounds (2-butanone, ethanol and 2-butanol). Nevertheless, lactose and citrate metabolisms differed between the three trials and some free amino acids (Arg, Pro, Ser, Cit, Homocys) concentrations varied drastically during the ripening time course. CLSM micrographs showed that fat globules were disrupted during pressing and bacteria were preferentially localised at the fat/protein interface. As the lactic starter species were the same in the three trials and predominant during the cheese manufacture, the observed differences could result of one or several of the followings: (i) the raw milk microflora which showed to be different leading to growth or metabolism activity of particular subdominant populations during the process and the ripening; (ii) the more or less early lysis of the lactic starters; (iii) the possible interactions between raw milk microflora and the added starters. This extensive characterization of Cantal cheese provides a strong basis for building a rational concept of the key steps in which either technological actions or complementary microbial inoculation could be done in order to limit day to day variations.
\end{abstract}

raw milk cheese / manufacture / ripening / proteolysis / lipolysis / microbial ecosystem / microstructure

摘要 - 新鲜牛奶制造的法国原产地名号保护 Cantal 干酪的动力学特性。法国硬干酪 (Cantal) 在法国原产地名号保护 (PDO) 干酪产品中产量居于第三位。法国硬手酪的生产方法类似于 切达干酪, 两种干酪的生产过程都有磨碎和干盐腌渍和形成均匀盐渍凝块的过程。为了确

\footnotetext{
* Corresponding author (通讯作者): isabelle.defreitas@ rennes.inra.fr
} 
定法国硬干酪在制造过程中一些重要参数的作用, 本研究从一个工厂内取 3 批样品, 研究 了从原料奶到干酪成熟 120 天内的整个生产过程及与干酪成熟期内 9 个关键阶段的动力学 特性。采用菌落计数方法及直接提取 DNA 和 PCR- 时间温度梯度凝胶电泳的方法探讨了法 国硬干酪的微生物区系。根据细胞内乳酸脱氢酶的活性定量地测定了乳酸菌的溶解; 并且 评价了碳源的变化、可溶性盐、蛋白质的水解、脂肪水解以及中性挥发性化合的形成。采 用激光共焦扫描显微镜 (CLSM) 观察了干酪微观结构的变化和细菌的定殖。试验证明控制 干酪加工条件和使用复杂混合发酵剂能够生产出非常相似的成熟干酪。在干酪的组成 (特别 是总固形物、脂肪、含氮化合物 $) 、$ 脂肪水解 $(0.7 \pm 0.2 \%$ 占脂肪的量 $)$ 、最终的蛋白的水解 程度 (34.4 $\mathrm{g} \cdot \mathrm{kg}^{-1}$, 水相中游离氨基酸的量) 以及干酪中主要中性挥发性化合物 (2-丁酮、乙 醇和 2-丁醇) 都非常相似。然而, 在 3 个试验组中乳糖、柠檬酸盐的代谢则不相同, 在整 个成熟时间内, 部分游离氨基酸( 精氨酸、脯氨酸、丝氨酸、瓜氨酸、同型半胱氨酸) 的浓 度变化显著。CLSM 的显微图像显示了在压制过程中脂肪球的破裂和细菌被优先地定殖在 脂肪和蛋白的交接面上。由于 3 个试验组所用的乳酸菌发酵剂相同, 这些乳酸菌在整个干 酪制造过程中都是优势菌群，但是所观察到的差别可能是由以下一种或几种原因造成的: (1) 由于鲜奶中微生物菌群不同, 因而导致在整个加工和成熟过程中一些特殊的次级微生物的 生长和具有代谢活性; (2) 乳酸菌发酵剂存在多或少的早期溶解; (3) 鲜奶中的微生物和发酵 剂之间可能存在相互作用。通过对法国硬干酪化学性质、生化性质和微生物的研究, 将对 干酪的工业生产起到指导性的作用。

\section{鲜奶干酪 / 制造 / 成熟 / 蛋白水解 / 脂肪水解 / 微生物生态系统 / 微观结构}

Résumé - Caractérisation fine du fromage AOC français Cantal au lait cru. Le fromage de Cantal est, en tonnage, la 3ème Appellation d'Origine Contrôlée française. Son procédé de fabrication, similaire à celui du Cheddar, implique une étape de broyage et salage à sec, qui résulte en un caillé salé homogène. Afin de déterminer les paramètres clé du procédé de fabrication agissant sur les caractéristiques spécifiques de cette variété de fromage, une étude approfondie et cinétique avec trois répétitions a été menée à 9 stades, du lait cru au fromage affiné 120 jours. L'écosystème microbien a été exploré par énumération et par extraction directe de l'ADN et PCR-Temporal Temperature Gradient Electrophoresis. La lyse des bactéries lactiques a été appréhendée par mesure de l'activité de la lactate déshydrogénase intracellulaire. Les changements intervenant dans les sources carbonées, la solubilisation des minéraux, la protéolyse, la lipolyse et l'apparition des composés volatiles neutres ont aussi été évalués. Les modifications de la microstructure du fromage ainsi que la localisation des bactéries ont été déterminées pas microscopie confocale à balayage laser (CLSM). La mise en œuvre de conditions de fabrication très contrôlées et l'utilisation d'un levain complexe a conduit à des fromages affinés très similaires, tant sur le plan de la composition (en particulier l'extrait sec total, la matière grasse, les formes azotées) des niveaux de lipolyse $(0.7 \pm 0.2 \%$ de la matière grasse) et de protéolyse $\left(34,4 \mathrm{~g} \cdot \mathrm{kg}^{-1} \mathrm{~d}\right.$ 'acides aminés libres dans le jus) que sur le plan des teneurs en composés volatiles majoritaires (2-butanone, éthanol et 2-butanol). Néanmoins, les métabolismes du lactose et du citrate différaient entre les trois essais, ainsi que les concentrations en certains acides aminés libres (Arg, Pro, Ser, Cit, Homocys) qui variaient fortement au cours de l'affinage. Les photographies obtenues par CLSM montraient que les globules gras étaient brisés lors du pressage et que les bactéries étaient préférentiellement localisées à l'interface matière grasse/protéine. Comme le levain utilisé comportaient les mêmes espèces pour les trois essais et que celles-ci s'avéraient dominantes au cours de la fabrication, les différences observées peuvent résulter : (i) des variations observées dans la flore indigène du lait cru conduisant à la croissance ou l'activité métabolique de populations sous-dominantes particulières pendant la fabrication ou l'affinage ; (ii) de la lyse plus ou moins précoce des espèces du levain ; (iii) des interactions possibles entre la flore indigène du lait cru et le levain ajouté. Cette caractérisation approfondie du fromage Cantal offre une base solide pour construire un concept rationnel des étapes-clé au cours desquelles soit des actions technologiques, soit une inoculation microbienne complémentaire peuvent être réalisées afin de limiter les variations journalières et d'optimiser la qualité globale.

fromage au lait cru / fabrication / affinage / protéolyse / lipolyse / écosystème microbien / microstructure 


\section{INTRODUCTION}

Cantal cheese is the third most produced PDO (Protected Denomination of Origin) cheese variety in France with an annual production of $18000 \mathrm{~T}$ [5]. Its making process is very similar to the Cheddar. Processing temperatures and acidification kinetics are slightly different but both manufacturing procedures involve a main bioconversion of lactose in lactic acid in structured pieces of curd (slabs for Cheddar; tome for Cantal) followed by curd milling, a dry salting step and pressing in order to get cylindrical cheese loaves of 30 to $40 \mathrm{~kg}$. Cantal is made either from raw or from pasteurised milk.

In a previous paper [8], two commercial Cantal cheeses were characterised on diverse aspects: physico-chemistry, microbiology, and microstructure. The results, which represented the first complete description of ripened Cantal cheese, demonstrated many similarities with Cheddar cheese in gross composition, fat microstructure, volatile compounds content and composition. However, Cantal at identical ripening times has higher $\mathrm{Ca}_{\mathrm{T}}$ and proteolysis levels than Cheddar. These differences were hypothesised as respectively resulting from differences in the time course of acidification during the different steps of the making processes and from the growth and metabolism of the microbial ecosystem originated by raw milk and added starters. Indeed, the microbial ecosystem naturally present or added to raw milk for making Cantal appears much more complex than the one used for making Cheddar $[4,16]$. However, this preliminary study did not show how the different steps of the cheesemaking process from the cheese milk to the ripening conditions led to the determined characteristics of ripened PDO Cantal cheese. Thus, to better understand raw milk Cantal cheese and the complex biochemical and microbiological mechanisms involved in its manufacture and ripening, a descriptive kinetic study (repeated three times) was carried out. Cheeses and the corresponding whey or internal juices were characterised at six main manufacturing process steps and at three ripening times.

\section{MATERIALS AND METHODS}

\subsection{Cheesemaking process and samples}

The samples were obtained from three Cantal productions manufactured in the same industrial plant between May and July 2004 through a process using $12000 \mathrm{~L}$ of bulk raw milk per vat with addition of proprietary commercial lactic starters (F-DVS DCC-260 and CHN19 of Chr. Hansen, Arpajon, France) in order to get an inoculum of $10^{5} \mathrm{cfu} \cdot \mathrm{mL}^{-1}$. Standardized milks (protein: fat $=0.94$ ) were heated to $31^{\circ} \mathrm{C}$ before addition of rennet $\left(33 \mathrm{~mL} \cdot 100 \mathrm{~L}^{-1}\right)$ resulting in coagulation after around $20 \mathrm{~min}$. After another six min after, curd cutting took place until wheat-sized curd grains were obtained. The mixture of curd and whey was then transferred to a "pre-pressing" vat in which whey drainage and mechanic pressing (about $3500 \mathrm{~kg} \cdot \mathrm{m}^{2}$ ) took place for $20 \mathrm{~min}$ at room temperature. The "prepressed" curd was cut in $2 \mathrm{~kg}$ pieces and placed in $50 \mathrm{~kg}$ moulds in which curd was turned and pressed four to six times in pressure cycles of $15 \mathrm{~min}$ with an increase from $3200 \mathrm{~kg} \cdot \mathrm{m}^{2}$ to $3800 \mathrm{~kg} \cdot \mathrm{m}^{2}$. Then, the pressed curd was cut in $15 \mathrm{~kg}$ pieces and matured for $14 \mathrm{~h}$ at $19^{\circ} \mathrm{C}$ in order to obtain the "tome". This tome was milled, mixed with $2.0 \%$ dry salt at $17{ }^{\circ} \mathrm{C}$, moulded and pressed for $48 \mathrm{~h}$ (pressure was increased from $8500 \mathrm{~kg} \cdot \mathrm{m}^{2}$ to $18000 \mathrm{~kg} \cdot \mathrm{m}^{2}$ ). After removal from the moulds, cheeses were ripened at $10{ }^{\circ} \mathrm{C}, 95 \%$ relative humidity.

For each production, nine samples were analysed: raw milk just before rennet addition $\left(\mathrm{T}_{0}\right)$, curd after coagulation $\left(\mathrm{T}_{30 \mathrm{~min}}\right)$ and the corresponding whey, curd after draining $\left(\mathrm{T}_{1 \mathrm{~h} 30}\right)$ and the corresponding whey, tome after maturation $\left(\mathrm{T}_{14 \mathrm{~h}}\right)$ and its cheese aqueous phase, salted tome $\left(\mathrm{T}_{15 \mathrm{~h}}\right)$ and its cheese aqueous phase, cheese after demoulding $\left(\mathrm{T}_{3 \mathrm{~d}}\right)$ and its cheese aqueous phase, cheeses after 30,60 and $120 \mathrm{~d}$ of ripening and their respective cheese aqueous phases. The size of curd and cheese samples was around $5 \mathrm{~kg}$.

Microbiological analyses were performed immediately in the plant on the milk, curds, young cheeses and whey samples. 
All other samples were stored at either $4{ }^{\circ} \mathrm{C}$ for physico-chemical analyses, $-20{ }^{\circ} \mathrm{C}$ for minerals and free amino-acids and $-80{ }^{\circ} \mathrm{C}$ for neutral volatile compounds and free fatty acids.

\subsection{Extraction of cheese aqueous phase (juice) and lipidic phase}

The cheese aqueous and lipidic phases were expressed by hydraulic press according to a previously described procedure [38].

\subsection{Somatic cells enumeration}

Raw milk somatic cells counts were determined with the Fossomatic (Foss Electric, Hilerød, Denmark) method.

\subsection{Microbiological analyses}

\subsubsection{Bacterial enumeration}

Milk, curd, whey and cheese (inner part) samples were enumerated as previously described [8]. Average results were expressed as $\log _{10}$ colony-forming units (cfu) per gram of cheese.

\subsubsection{PCR-Temporal Temperature Gel Electrophoresis (TTGE)}

DNA was extracted from $1 \mathrm{~mL}$ cell cultures and cheeses homogenized in trisodium citrate. The pellets obtained after centrifugation at $10000 \times g$ for 10 min were re-suspended in $200 \mu \mathrm{L}$ (cell cultures) or $400 \mu \mathrm{L}$ (homogenized cheeses) of lysis buffer $\left(20 \mathrm{mmol} \cdot \mathrm{L}^{-1}\right.$ Tris $\mathrm{HCl}(\mathrm{pH} 8)$, $2 \mathrm{mmol} \cdot \mathrm{L}^{-1}$ EDTA, $1.2 \%$ Triton X100, $20 \mathrm{mg} \cdot \mathrm{mL}^{-1}$ lysozyme, $50 \mathrm{U} \cdot \mathrm{mL}^{-1} \mathrm{mu}$ tanolysine) and incubated at $37^{\circ} \mathrm{C}$ for $1 \mathrm{~h}$. Then DNA extraction and purification were performed as described in the Dneasy tissue kit instructions (Qiagen, Courtaboeuf, France).

PCR amplification was performed using V3P3-GC-Clamp (5'-GCCCGCCGCGCGCGGCGGGCGGGGCGGGGGCACGGGGGGCCTCGGGAGGCAGCAG-3') and V3P2 (5'-ATTACCGCGGCTGCTGG-3') primers directed to the $\mathrm{V} 3$ region of the $16 \mathrm{~S}$ rRNA gene and giving PCR products of about $233 \mathrm{bp}$. The PCR mixture
$(50 \mu \mathrm{L})$ contained: Taq polymerase buffer $\left(10 \mathrm{mmol} \cdot \mathrm{L}^{-1} \quad\right.$ Tris- $\mathrm{HCl} \quad(\mathrm{pH} 9.0)$, $50 \mathrm{mmol} \cdot \mathrm{L}^{-1} \mathrm{KCl}, 1.5 \mathrm{mmol} \cdot \mathrm{L}^{-1} \mathrm{MgCl}_{2}$ ), $200 \mu \mathrm{mol} \cdot \mathrm{L}^{-1}$ of desoxynucleoside triphosphate mix, $1 \mu \mathrm{mol} \cdot \mathrm{L}^{-1}$ of each primer, $2.5 \mathrm{U}$ of Taq polymerase (Q-BIOgene, Illkirch, France) and $1 \mu \mathrm{L}$ of template DNA. PCR amplification was performed on iCycler Therman Cycler (BIO-RAD Laboratories, Hercules, CA, USA). The amplification program was $94^{\circ} \mathrm{C}$ for $2 \mathrm{~min}$; 35 cycles of $95^{\circ} \mathrm{C}$ for $30 \mathrm{~s}, 63^{\circ} \mathrm{C}$ for $30 \mathrm{~s}$ and $72{ }^{\circ} \mathrm{C}$ for $1 \mathrm{~min}$; and finally $72{ }^{\circ} \mathrm{C}$ for $5 \mathrm{~min}$. The purity and length of the PCR products were checked on $1.5 \%(\mathrm{w} / \mathrm{v})$ agarose gel (Euronio, Les Ulis, France) with a $100 \mathrm{pb}$ DNA ladder (Fermentas life sciences, Vilnius, Lithuania).

To separate the V3 region PCR products by TTGE analysis, the Dcode universal mutation detection system was used (BIORAD). PCR product $(10 \mu \mathrm{L})$ was added to $5 \mu \mathrm{L}$ of loading buffer $(0.05 \%$ bromophenol blue, $0.05 \%$ xylene cyanol and $70 \%$ glycerol). Gels were prepared with $10 \%$ (w/v) acrylamide/bis (37.5:1), $7 \mathrm{~mol} \cdot \mathrm{L}^{-1}$ urea and run with $1.25 \mathrm{X}$ TAE buffer $\left(2 \mathrm{~mol} \cdot \mathrm{L}^{-1}\right.$ Tris base, $1 \mathrm{~mol} \cdot \mathrm{L}^{-1}$ glacial acetic acid, $50 \mathrm{mmol} \cdot \mathrm{L}^{-1}$ EDTA (pH 8). Migration was performed at $41 \mathrm{~V}$ for $16 \mathrm{~h}$ with a temperature gradient of $63{ }^{\circ} \mathrm{C}$ to $70{ }^{\circ} \mathrm{C}$ (rate of $\left.0.4^{\circ} \mathrm{C} \cdot \mathrm{h}^{-1}\right)$. Gels were stained with ethidium bromide for $15 \mathrm{~min}$ and photographed on a UV transillumination table. A TTGE ladder composed of thirteen reference strains was prepared by pooling PCR products from pure cultures.

Bacterial species were presumptively identified by comparison with the bacterial reference database after gel normalization using the Bionumerics software, version 2 (Applied Maths, Kortrijk, Belgium). As the TTGE ladder composition was known, bands identified on the profile are known to be due to the reference strains. However, in cheese samples a band (for example band $\mathrm{j}$ in Fig. 1) may represent a number of different species which have the same migration distances and hence it is impossible to distinguish between certain species by this method. 


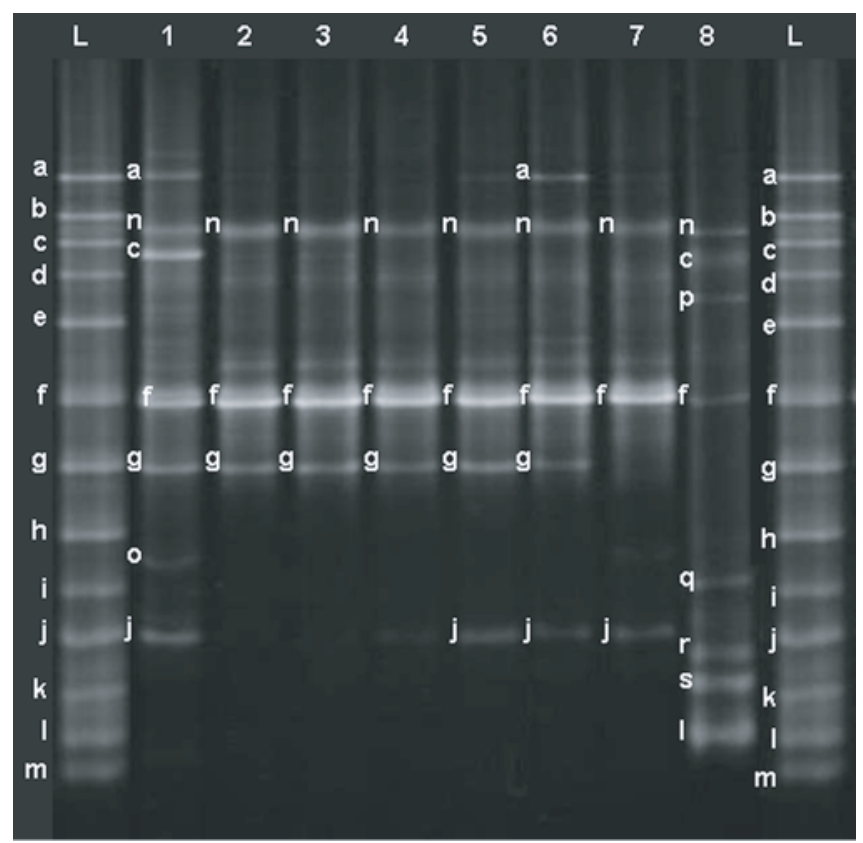

The PCR control is negative without any band (not shown).

The different samples analyzed were: raw milk with commercial starter (lane 1), matured tome (lane 2), salted tome (lane 3), $3 \mathrm{~d}$ cheese (lane 4), $30 \mathrm{~d}$ cheese (lane 5), $60 \mathrm{~d}$ cheese (lane 6), $120 \mathrm{~d}$ cheese (lane 7) and a rind

The TTGE ladder is a mix of the PCR amplifications obtained from the 13 following strains: a) Lactobacillus plantarum CNRZ211, b) Lactobacillus fermentum CNRZ209T, c) Enterococcus faecium CNRZ149, d) Lactobacillus helveticus CNRZ223T, e) Enterococcus faecalis CNRZ137, f) Lactococcus lactis CNRZ105, g) Streptococcus thermophilus CIP102303, h) Corynebacterium moorparkense CIP107183 ${ }^{\mathrm{T}}$, i) Lactobacillus reuteri DSM200016, j) Lactobacillus paracasei LMG9192, k) Arthrobacter nicotianae CIP82107T , I) Brevibacterium casei CIP102111 ${ }^{\mathrm{T}}$ and $\left.\mathbf{m}\right)$ Propionibacterium cyclohexanicum TL1365.

Bacterial species were presumptively identified by comparison with the bacterial reference database. In cheese samples a same band may represent a number of different species (see Materials and Methods). According to the database, $\mathbf{n}$ ) is presumed as Leuconostoc cremoris or Staphylococcus equorum, o) Bacillus pumilis or Corynebacterium flavescens, p) Lactobacillus delbrueckii subsp. lactis, q) Lactobacillus reuteri or Microbacterium gubbeenense, r) Corynebacterium casei or Brachybacterium sp. or Arthrobacter sp. and s) Brevibacterium linens.

Figure 1. Bacterial changes during PDO Cantal cheese manufacture and ripening monitored by temporal temperature gradient electrophoresis (TTGE).

\subsubsection{Intracellular lysis marker}

For each cheese, $20 \mathrm{~g}$ were aseptically weighed, diluted to $80 \mathrm{~mL}$ with distilled water in a stomacher bag (Laboratories Humeau, La Chapelle-sur-Erdre, France) and blended in a Stomacher lab-blender 400 (Laboratories Humeau) for $3 \mathrm{~min}$. The mixture was stored at $-20^{\circ} \mathrm{C}$ until used. Total L-lactate dehydrogenase activity (LDH) was assayed in triplicate by the method of Cogan et al. [6] using pyruvate as substrate and fructose-1.6-biphosphate (FBP) as cofactor. Utilisation of the co-factor FBP allowed the distinction between lactobacilli$\mathrm{LDH}$ (FBP not requested for activation) and lactococci-LDH (FBP requested for activation). Activity was expressed as units per $\mathrm{g}$ of cheese, where one unit was defined as the amount of enzyme which catalyses the 
oxidation of $1 \mu \mathrm{mol}$ of $\mathrm{NADH}$ per min at $20{ }^{\circ} \mathrm{C}$.

\subsection{Compositional analyses}

Compositional analyses were performed on the core fraction of the grated cheeses after removal of the outer surface $(2 \mathrm{~cm}$ below the surface). Determination of fat, $\mathrm{pH}$, total solids (TS), ash, total nitrogen $\mathrm{N} \times 6.38$ (TN), non casein nitrogen (NCN) measured at $\mathrm{pH} 4.4$ for cheese and at $\mathrm{pH} 4.6$ for juice (water soluble nitrogen) and non protein nitrogen soluble in $12 \%$ trichloroacetic acid (NPN), total phosphorus, mineral cations (calcium, magnesium, potassium and sodium), anions (lactate, chlorides, inorganic phosphate, citrate) were performed as previously described [8]. The average and standard deviation (SD) of duplicate or triplicate determinations are presented. For an easier comparison between cheese, whey and extracted cheese juice, composition of soluble components is expressed for $1000 \mathrm{~g}$ of water for cheese or whey or juice [8].

In addition, the size distribution of fat globules was determined in raw milks by laser light scattering (LLS) using a Mastersizer 2000 (Malvern Instruments, Malvern, UK) as described by Michalski et al. [31]. The used refractive indices were 1.458 for the anhydrous milk fat and 1.333 for the dispersing water at $633 \mathrm{~nm}$ as recommended [31].

\subsection{Assessment of proteolysis}

\subsubsection{Electrophoretic profiles by urea-PAGE}

Electrophoretic profiles of the different caseins were obtained by urea-PAGE. One part of cheese was diluted in two parts of denaturation solution $\left(0.133 \mathrm{~mol} \cdot \mathrm{L}^{-1}\right.$ Tris$\mathrm{HCl}, \mathrm{pH} 6.8,9 \mathrm{~mol} \cdot \mathrm{L}^{-1}$ urea, $5 \%$ (v/v) $\beta$ mercaptoethanol (Merck, Nogent-sur-Marne, France), $10 \%$ glycerol (w/v) (Sigma, St Louis, MO, USA) and bromophenol blue (BIO-RAD) made up to $10 \mathrm{~mL}$ with distilled water), incubated for one hour in a water bath at $37^{\circ} \mathrm{C}$. Acrylamide gels were prepared as previously described [39]. Migration was performed for $30 \mathrm{~min}$ at room temperature in a Mini-protean II (BIO-RAD) at constant voltage of $200 \mathrm{~V}$.

\subsubsection{Peptidic profiles by RP-HPLC}

Peptidic profiles were assessed by reverse phase high performance liquid chromatography (RP-HPLC) on a C18 column [8].

\subsubsection{Free amino acids}

Free amino acids contents were determined after deproteinisation of samples by sulfosalicylic acid according to the method described by Saboya et al. [37].

\subsection{Assessment of lipolysis}

Individual free fatty acids (FFA) were extracted from the cheese and quantified according to the method of De Jong and Badings [9]. Three independent extractions of cheese lipids were performed using aminopropyl solid phase extraction columns (500 mg/3 mL, Phenomenex Torrance, CA, USA) and a vacuum Manifold Maclerey Nagel (Duren, Deutshland). Individual FFA (C4:0, C6:0, C8:0, C10:0, C12:0, C14:0, C16:0, C18:0, C18:1, C18:2 and C18:3) were quantified by GC using a Varian 3800 Gas Chromatograph with flame ionisation detection (FID), a Varian 1079 Universal capillary injector, a Varian 8410 liquid autosampler and Varian Star operating software (Varian Analytical Instruments, Harbor City, California, USA). The column used was a fused silica semi-capillary column BP21 (SGE) (length: $25 \mathrm{~m}$; diameter: $0.53 \mathrm{~mm}$; film thickness: $0.5 \mu \mathrm{m}$ ) with direct on-column injection. Injection temperature was $65^{\circ} \mathrm{C}$, then increased to $250{ }^{\circ} \mathrm{C}$ at a rate of $200^{\circ} \mathrm{C} \cdot \mathrm{min}^{-1}$, then held for $1 \mathrm{~min}$ followed by cooling to $65^{\circ} \mathrm{C}$ at a rate of $200^{\circ} \mathrm{C} \cdot \mathrm{min}^{-1}$ and held for $20 \mathrm{~min}$. The FID temperature was $250{ }^{\circ} \mathrm{C}$. The flow rate of the carrier gas (helium) was $9.7 \mathrm{~mL} \cdot \mathrm{min}^{-1}$ at $65^{\circ} \mathrm{C}$. Cheese samples were analysed at 60 and $120 \mathrm{~d}$ of ripening. The values for triplicates did not vary by more than $15 \%$.

\subsection{Volatile analysis}

Neutral volatile compounds were extracted and identified by dynamic headspace analysis coupled to gas chromatograph and mass spectrometry from $4 \mathrm{~g}$ juice samples 
according to Thierry et al. [40]. Juice samples were chosen for analysis of the neutral volatile compounds in Cantal cheeses, because previous results reported that the profiles of volatiles obtained from either cheese aqueous phase, cheese oil, or cheese samples were very similar [8]. Quantification was performed by integrating the peak areas of total ion current (TIC) chromatograms.

Ethanol content was determined by an enzymatic method using Boehringer kits (R-Biopharm, St Didier au Mont d'Or, France).

\subsection{Microstructure and localisation of bacteria}

Cantal cheese microstructure and bacterial localization were determined using confocal laser scanning microscopy (CLSM) as previously described by Lopez et al. [26]. The supramolecular organization of both the fat and protein network were characterized in the matured tome $\left(\mathrm{T}_{14 \mathrm{~h}}\right)$, salted curd grains $\left(T_{15 h}\right)$ and in cheeses after 3, 30, 60 and $120 \mathrm{~d}$ of ripening using a methodology previously described [8].

\subsection{Statistical analyses}

Microbiological, compositional, free amino acids, free fatty acids and volatile compounds concentrations data from the three batches of each compound were used for statistical analysis. One-way analyses of variance (ANOVA) were performed by using the General Linear Model procedure of Statgraphics Plus (Statistical Graphic Corp., Englewood Cliffs, NJ, USA) to determine the effect of ripening stage on the concentration data of each compound. The Fisher's least significant difference (LSD) test was used to determine differences at 95\% confidence level $(\alpha<0.05)$.

\section{RESULTS AND DISCUSSION}

\subsection{Raw milk characterisation}

The main biochemical parameters: nitrogen compounds, fat content, minerals (Tab. I), fat globules size distribution (particles from 1 to $10 \mu \mathrm{m}$ of diameter centred on $4 \mathrm{mi}-$ crons) and somatic cell counts (from $2.54 \times 10^{5}$ to $3.01 \times 10^{5}$ cells $\cdot \mathrm{ml}^{-1}$ ) of the three bulk raw milks used for Cantal cheeses manufacture were within the range of milk usually collected in France.

Populations of total mesophilic flora (4.7 $\left.\log _{10} \quad \mathrm{cfu} \cdot \mathrm{mL}^{-1}\right)$, lactococci (4.6 $\left.\log _{10} \mathrm{cfu} \cdot \mathrm{mL}^{-1}\right), \quad S$. thermophilus $\left(4.3 \log _{10} \mathrm{cfu} \cdot \mathrm{mL}^{-1}\right)$, mesophilic lactobacilli (3.4 $\log _{10} \mathrm{cfu} \cdot \mathrm{mL}^{-1}$ ), facultative heterofermentative lactobacilli $\left(3.0 \log _{10} \mathrm{cfu} \cdot \mathrm{mL}^{-1}\right)$, thermophilic lactobacilli $\left(2.8 \log _{10} \mathrm{cfu} \cdot \mathrm{mL}^{-1}\right)$, corynebacteria $\left(3.5 \log _{10} \mathrm{cfu} \cdot \mathrm{mL}^{-1}\right)$, propionibacteria $\left(3.3 \log _{10} \mathrm{cfu} \cdot \mathrm{mL}^{-1}\right)$ and enterococci $\left(3.0 \log _{10} \mathrm{cfu} \cdot \mathrm{mL}^{-1}\right)$ detected were very similar between the raw milks used for the three trials (standard deviations lower than $0.4 \log$ ) and were in agreement with results previously reported for raw milk used in Salers cheese [13], another Cantal variety made in the same area. In contrast, a larger range of variation was observed for total coliforms (2.3 to $\left.4.0 \log _{10} \mathrm{cfu} \cdot \mathrm{mL}^{-1}\right)$, Pseudomonas (2.3 to $\left.4.9 \log _{10} \mathrm{cfu} \cdot \mathrm{mL}^{-1}\right)$. Such a variation was previously observed in Camembert cheese raw milk [10]. Surprisingly, yeasts counts were between 4.1 to $6.4 \log _{10} \mathrm{cfu} \cdot \mathrm{mL}^{-1}$. Such a variability of yeast population being poorly documented, additional enumerations were performed in samples of incoming raw milks, over a period of $15 \mathrm{~d}$. They showed a range of variation between 2.3 to $6.0 \log _{10} \mathrm{cfu} \cdot \mathrm{mL}^{-1}$ which interrogate about the necessity to acquire a deeper knowledge on the sources of milk contamination by this micro-organism.

\subsection{Microbiological analysis during the manufacture of Cantal cheese}

Figure 1 shows the dominant bacterial populations detected by PCR-TTGE at different stages of manufacture and ripening of Cantal cheese: raw milk with added commercial starter, matured tome, salted tome and cheeses at 3,30,60, $120 \mathrm{~d}$ of ripening as well as a rind sample.

Similar profiles were obtained for the three trials. The technique used gives an indication of the bacterial populations present at levels greater than $1 \%$ of the total flora [14]. As expected, in the raw milk inoculated 
Table I. Changes in composition (carbon sources, minerals and nitrogen compounds) of whey and juice during manufacture of PDO Cantal cheeses. Values are means and standard deviations of two or three determinations for three cheese trials.

\begin{tabular}{|c|c|c|c|c|c|c|}
\hline \multirow{2}{*}{$\begin{array}{l}\text { Content }^{\mathrm{a}} \\
\left(\mathrm{g} \cdot \mathrm{kg}^{-1} \text { water }\right)\end{array}$} & \multicolumn{5}{|c|}{ Manufacture steps } & \multirow[b]{2}{*}{$P^{\mathrm{c}}$} \\
\hline & Milk & $\begin{array}{l}\text { Whey } \\
(0.5 \mathrm{~h})\end{array}$ & $\begin{array}{c}\text { Draining } \\
\text { whey }(1.5 \mathrm{~h})\end{array}$ & $\begin{array}{l}\text { Matured tome } \\
\text { juice (14h) }\end{array}$ & $\begin{array}{l}\text { Salted tome } \\
\text { juice }(15 \mathrm{~h})\end{array}$ & \\
\hline $\mathrm{pH}$ & $6.64 \pm 0.12$ & $6.64 \pm 0.05$ & $6.57 \pm 0.14$ & $\begin{array}{r}4.97 \pm \\
0.06\end{array}$ & $5.11 \pm 0.07$ & *** y \\
\hline Acidity $\left(\right.$ Dornic $^{\circ}$ ) & $15 \pm 1$ & $8 \pm 1$ & $9 \pm 1$ & $115 \pm 4$ & 994 & $* * * \pi$ \\
\hline Total solids & $138.9 \pm 3.6$ & 74.60 .3 & $79.1 \pm 7.3$ & $92.5 \pm 1.4$ & $149.7 \pm 4.7$ & $* * * \pi$ \\
\hline Ash & $8.1 \pm 0.1$ & $5.7 \pm 0.1$ & $5.5 \pm 0.1$ & $26.0 \pm 0.8$ & $80.1 \pm 3.4$ & $* * * \pi$ \\
\hline \multicolumn{7}{|l|}{ Carbon sources } \\
\hline Lactose & $55.0 \pm 0.9$ & $\mathrm{ND}^{\mathrm{b}}$ & $49.0 \pm 3.2$ & $9.8 \pm 3.7$ & $11.5 \pm 1.9$ & $* * * y$ \\
\hline Lactate & $0.1 \pm<0.1$ & $0.1 \pm 0.1$ & $0.3 \pm 0.1$ & $39.9 \pm 2.9$ & $43.3 \pm 3.8$ & $* * * \pi$ \\
\hline Citrate & $1.7 \pm 0.1$ & $1.6 \pm 0.1$ & $1.2 \pm 0.4$ & $0.8 \pm 0.2$ & $1.0 \pm 0.2$ & $* * y$ \\
\hline \multicolumn{7}{|l|}{ Minerals } \\
\hline Sodium & $0.5 \pm<0.1$ & $0.4 \pm<0.1$ & $0.4 \pm<0.1$ & $0.5 \pm 0.1$ & $23.4 \pm 0.8$ & $* * * \pi$ \\
\hline Chloride & $1.4 \pm 0.1$ & $1.5 \pm 0.2$ & $1.2 \pm 0.3$ & $2.3 \pm 1.1$ & $39.9 \pm 3.4$ & $* * * \pi$ \\
\hline Potassium & $2.0 \pm 0.3$ & $1.9 \pm 0.2$ & $1.9 \pm 0.2$ & $2.7 \pm 0.3$ & $2.6 \pm 0.2$ & $* * * \pi$ \\
\hline Calcium & $1.4 \pm<0.1$ & $0.4 \pm<0.1$ & $0.4 \pm<0.1$ & $7.1 \pm 0.8$ & $5.9 \pm 0.2$ & $* * * \pi$ \\
\hline Inorganic phosphate & $2.0 \pm 0.2$ & $1.0 \pm 0.1$ & $0.8 \pm 0.3$ & $4.7 \pm 0.3$ & $4.3 \pm 0.3$ & $* * * \pi$ \\
\hline \multicolumn{7}{|l|}{ Nitrogen compounds } \\
\hline Total nitrogen & $37.0 \pm 1.1$ & $10.2 \pm 0.2$ & $10.0 \pm 0.4$ & $28.6 \pm 1.2$ & $29.7 \pm 3.5$ & *** 入 \\
\hline $\begin{array}{l}\text { Non caseinic } \\
\text { nitrogen }\end{array}$ & $8.4 \pm 0.2$ & $9.5 \pm 0.3$ & $9.3 \pm 0.4$ & $23.7 \pm 1.8$ & $22.4 \pm 1.8$ & $* * * \pi$ \\
\hline Non proteic nitrogen & $2.0 \pm 0.1$ & $2.3 \pm 0.1$ & $2.3 \pm 0.1$ & $10.4 \pm 1.4$ & $9.8 \pm 1.1$ & $* * * \pi$ \\
\hline
\end{tabular}

a Results are expressed per kg of water in order to allow direct comparisons of solubilised compounds over the ripening.

b ND: not determined.

${ }^{c}$ Results of the analysis of variance (without the milk values): probability of F-test. $* 0.05 \leq P<0.01$;

** $0.01 \leq P<0.001 ; * * * P \leq 0.001$. The direction of variation during ripening is symbolized by an arrow.

with commercial starters (lane 1), the main bands corresponded to Leuconostoc cremoris (n), Lactococcus lactis (f), Streptococcus thermophilus (g) and Lactobacillus paracasei/casei/rhamnosus (j). Other bands identified were presumed to come from the raw milk flora: Lactobacillus plantarum (a), Enterococcus faeciens/Lactobacillus brevis (c), Bacillus pumilis/Corynebacterium flavescens $(\mathrm{o})$.

In the matured (lane 2) and salted (lane 3) tomes, the dominant species identified were 
L. lactis (f), S. thermophilus (g) and Leuconostoc cremoris (n). Indeed L. lactis and $S$. thermophilus, the main acidifying species, had reached their maximal level by the end of acidification $\left(>9 \log _{10} \mathrm{cfu} \cdot \mathrm{g}^{-1}\right)$. This is similar to results reported for Salers cheese made without starter addition, in which the lactic acid bacterial counts were also maximal at the end of acidification stage and represented 57 to $71 \%$ of the total bacteria [13].

As sub-dominant populations of the microflora could not be detected by PCRTTGE, they were enumerated on selective media. At the end of acidification $\left(\mathrm{T}_{14 \mathrm{~h}}\right)$, corynebacteria, propionibacteria, enterococci and yeast populations had reached $6.3 \pm 1.0 \log _{10} \mathrm{cfu} \cdot \mathrm{g}^{-1}, 6.4 \pm 0.2 \log _{10} \mathrm{cfu} \cdot \mathrm{g}^{-1}$, $6.5 \pm 0.6 \log _{10} \mathrm{cfu} \cdot \mathrm{g}^{-1}$ and $6.5 \pm 2.2 \log _{10}$ $\mathrm{cfu} \cdot \mathrm{g}^{-1}$ respectively. Undesirable microflora were also observed to increase during manufacture. Indeed, coliforms reached on average $6.1 \pm 0.9 \log _{10} \mathrm{cfu} \cdot \mathrm{g}^{-1}$ and Pseudomonas $5.3 \pm 1.1 \log _{10} \mathrm{cfu} \cdot \mathrm{g}^{-1}$ after acidification. Salting was expected to induce an osmotic shock on the microflora by modifying the ionic balance in the cheese matrix [34] but salt addition had only a slight effect on populations of living microflora, at least immediately after salting $\left(\mathrm{T}_{15 \mathrm{~h}}\right)$ (data not shown). Small differences were observed between populations detected in the matured and salted tomes which are thought to originate from the mechanical operation of milling which may also homogenize the localization and distribution of colonies of microorganisms.

\subsection{Microbiological analysis during the ripening of Cantal cheese}

The starter species L. lactis (band f) and Leuconostoc (band $\mathrm{n}$ ) were observed by PCR-TTGE to remain predominant throughout the ripening of the three trials of Cantal cheese (Fig. 1, lanes 4-7). S. thermophilus (band g) was only detected up to $60 \mathrm{~d}$ of ripening after which the band disappeared. A band, $\mathrm{j}$, which according to the Bionumerics database could be attributed to L. paracasei/casei/rhamnosus, was not visible until demoulding $\left(\mathrm{T}_{3 \mathrm{~d}}\right)$ but was detected during the remainder of ripening.
A band corresponding to $L$. plantarum (band a), likely originated from the environment of the manufacturing plant or the raw milk, was detected only at $60 \mathrm{~d}$ reflecting that the balance of species of non starter acid lactic bacteria (NSLAB) changes during ripening. The rind (lane 8 ) exhibited a completely different profile with numerous species of high GC\% bacteria (Brevibacterium sp., Arthrobacterium sp., Brachybacterium sp., Corynebacterium sp.) and many Lactobacillus sp.

As PCR-TTGE revealed species from DNA extracted from either dead or live bacteria, traditional enumerations on selective media were performed to give a dynamic view during ripening. Lactococcal populations decreased significantly from $9.3 \pm 0.4 \log _{10} \mathrm{cfu} \cdot \mathrm{g}^{-1}$ at $3 \mathrm{~d}$ to $6.5 \pm$ $0.5 \log _{10} \mathrm{cfu}^{-\mathrm{g}^{-1}}$ at $120 \mathrm{~d}$ of ripening ( $p=$ 0.0007 ) while levels of $S$. thermophilus decreased from $9.1 \pm 0.2 \log _{10} \mathrm{cfu} \cdot \mathrm{g}^{-1}$ to $6.3 \pm$ $0.6 \log _{10} \mathrm{cfu} \cdot \mathrm{g}^{-1}(p=0.0071)$. The large increase in free FBP-dependent LDH (Fig. 2) with a maximal activity between 30 and $60 \mathrm{~d}$ of ripening indicated that the decrease in viability observed for lactococci and/or $S$. thermophilus was due to lysis. However, despite similar starters being used for the three trials, the kinetics of lysis differed from one trial to another (data not shown). This could alter the time at which the released intracellular enzymes gained access to their substrates and thus, the kinetics of ripening. The L-LDH detected had lost 80 to $90 \%$ activity by $120 \mathrm{~d}$ of ripening as previously reported to a lesser extent in Cheddar cheese [19]. The early release of lactococcal intracellular enzymes due to lysis occurs in numerous types of cheeses [27] and is considered to enhance or accelerate the flavor development.

Lactobacilli counts varied during ripening: enumerated mesophilic lactobacilli from $6.3 \pm 0.3 \log _{10} \mathrm{cfu}^{-1} \mathrm{~g}^{-1}$ at $3 \mathrm{~d}$ to $6.7 \pm$ $0.3 \log _{10} \mathrm{cfu} \cdot \mathrm{g}^{-1}$ at $120 \mathrm{~d}$, facultative heterofermentative lactobacilli from $6.1 \pm$ $1.6 \log _{10}$ cfu.g ${ }^{-1}$ to $7.4 \pm 0.2 \log _{10} \mathrm{cfu} \cdot \mathrm{g}^{-1}$. Concerning levels of sub-dominant microflora: corynebacteria varied from $5.9 \pm$ $0.7 \log _{10} \mathrm{cfu} \cdot \mathrm{g}^{-1}$ at $3 \mathrm{~d}$ to $5.4 \pm 0.4 \log _{10}$ $\mathrm{cfu} \cdot \mathrm{g}^{-1}$ at $120 \mathrm{~d}$, enterococci from $6.1 \pm$ $0.3 \log _{10} \mathrm{cfu} \cdot \mathrm{g}^{-1}$ to $5.5 \pm 0.4 \log _{10} \mathrm{cfu} \cdot \mathrm{g}^{-1}$, 


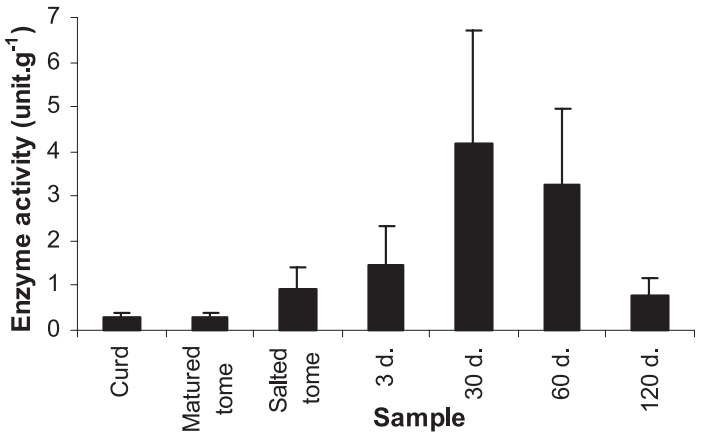

Figure 2. Levels of the fructose biphosphate (FBP) dependant lactococcal lactate dehydrogenase (L-LDH) activity detected in Cantal cheeses over manufacture and ripening. Error-bars show standard deviation of 9 determinations (3 replicates $\times 3$ trials). propionibacteria from $4.9 \pm 0.7 \log _{10} \mathrm{cfu} \cdot \mathrm{g}^{-1}$ to $5.6 \pm 0.3 \log _{10} \mathrm{cfu} \cdot \mathrm{g}^{-1}$ and yeasts from $5.3 \pm 0.4 \log _{10} \mathrm{cfu}^{-1}$ to $3.4 \pm$ $0.4 \log _{10} \mathrm{cfu} \cdot \mathrm{g}^{-1}$. Undesirable microflora (coliforms and Pseudomonas) decreased $(p=0.02)$ to reach $2.1 \pm 1.1 \log _{10} \mathrm{cfu} \cdot \mathrm{g}^{-1}$ and $2.4 \pm 0.3 \log _{10} \mathrm{cfu} \cdot \mathrm{g}^{-1}$ at $120 \mathrm{~d}$ of ripening.

\subsection{Localisation of bacteria}

The microstructural analysis performed in this study allowed the localisation of individual bacteria cells in situ in Cantal cheese (Fig. 3). The bacteria, observed after the maturation of the tome, were preferentially localized at the fat/paracasein interface and in pockets of whey (Fig. 3A). During ripening, the bacteria were localised both as individual cells close to fat inclusions (Fig. 3B and 3C) and as colonies in the protein network (Fig. 3D) as previously observed in several cheese varieties [26]. Because of the mechanical stress implemented to the rennet curd, some of the individual bacteria cells may have been expelled from the protein network and then, may have grown in pockets of whey surrounding the fat inclusions (Fig. 3A).

\subsection{Compositional analysis and biochemical indices during manufacture of Cantal cheese}

In the salted tome, total solids reached $549.3 \pm 7.8 \mathrm{~g} \cdot \mathrm{kg}^{-1}$, fat $253.8 \pm 4.1 \mathrm{~g} \cdot \mathrm{kg}^{-1}$, proteins $(\mathrm{N} \times 6.38) 213.2 \pm 10.6 \mathrm{~g} \cdot \mathrm{kg}^{-1}$ and ashes $45.6 \pm 2.8 \mathrm{~g} \cdot \mathrm{kg}^{-1}$. Table I summarises the changes in $\mathrm{pH}$, acidity, total solids, ash, carbon sources, minerals, $\mathrm{TN}, \mathrm{NCN}$ and NPN detected during the manufacture of Cantal cheese expressed. All biochemical results are expressed for $1000 \mathrm{~g}$ of water in order to make easier the comparison between the different products. Such a calculation can indeed be criticised because, as shown by Mocquot [32], some water is bound to cheese paracasein in a variable proportion according to many technological treatments (milk heating, acidification, proteolysis, etc.) and consequently not a solvent. For want of something better, this approach was chosen because it allowed precise characterisation of variations in the composition of the cheese aqueous phase resulting of what is going on in the cheese bioreactor. So expressed $\mathrm{NaCl}$ content was $63 \mathrm{~g}$, a value which is $50 \%$ higher than that of one day old Cheddar [18]. Acidification led to a $\mathrm{pH}$ decrease from $6.57 \pm 0.14$ to $4.97 \pm 0.06$ while acidity increased from $8^{\circ} \mathrm{D} \pm 1$ to $115 \pm 3{ }^{\circ} \mathrm{D}$. Twelve percent of milk lactose was metabolised in lactate during the pre-pressing step $\left(\mathrm{T}_{1.5 \mathrm{~h}}\right)$ and about $80 \%$ by the end of acidification $\left(T_{15 h}\right)$. The concentration of residual lactose in the matured tomes $\left(\mathrm{T}_{14 \mathrm{~h}}\right)$ varied from 9.0 to $13.8 \mathrm{~g} \cdot \mathrm{kg}^{-1}$ of water between the three trials. This difference is likely resulting of variation in the acidification metabolism of raw milk microflora. Only 2 to $3 \%$ of the milk lactose remained as galactose (data not shown). The other potential carbon source, citrate, was slowly metabolised: $60 \%$ of the initial content were still present in the juice of salted tome. 

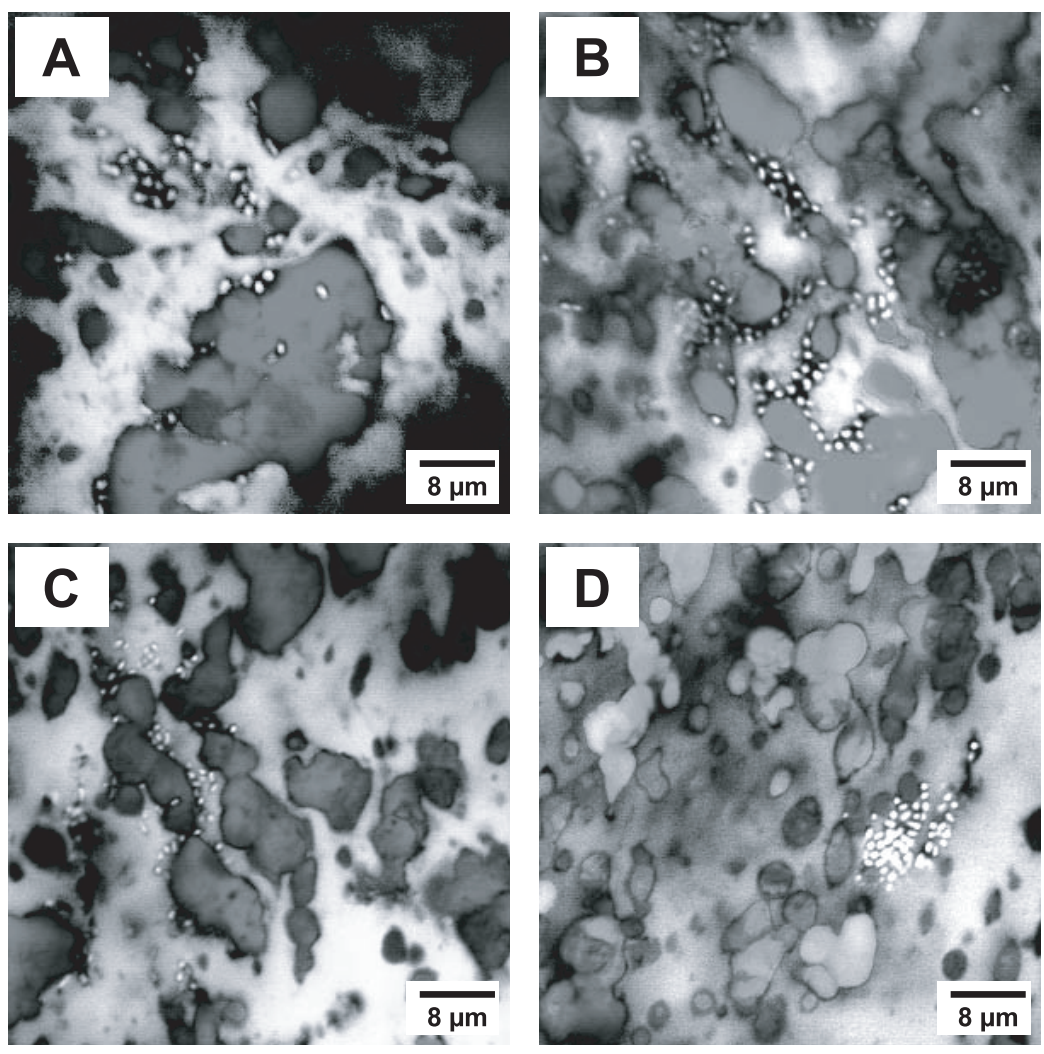

Figure 3. Localisation of the microflora at different stages of manufacture and ripening of Cantal cheeses : (A) matured and salted tome, (B) $30 \mathrm{~d}$ of ripening and (C and D) $120 \mathrm{~d}$ of ripening. Microflora appears as bright areas, fat appears in grey levels and proteins in white.

During the manufacture of Cantal cheese, soluble minerals were measured in the whey and juice of the matured and salted tomes. Lactose biotransformation in lactate induced a 4.7 fold increase of milk soluble minerals in the aqueous phase of the matured tome $\left(\mathrm{T}_{14 \mathrm{~h}}\right)$ compared to the initial whey. Soluble calcium increased 15 fold, inorganic phosphate increased 4.3 fold but there was no change in the molar ratio $\mathrm{Ca} /$ $\mathrm{P}$ which was close to one. The slight differences in the acidification between the three cheese trials also induced slight differences in calcium solubilisation. Soluble calcium contents varied by $12 \%$ (from 6.1 to $7.8 \mathrm{~g} \cdot \mathrm{kg}^{-1}$ of water) at $\mathrm{T}_{14 \mathrm{~h}}$, the lowest level being found as expected, in the cheese trial having the lowest rate of acidification. Milling and salting erased a large part of these differences in soluble $\mathrm{Ca}$ (Tab. I).

$\mathrm{NCN}$ and NPN levels in the cheese juice increased 2.5 and 4.3 fold respectively during manufacture. Through the use of the NCN values determined in the first drained whey $\left(\mathrm{T}_{0.5 \mathrm{~h}}\right)$, in salted tome and its juice, it was calculated that about $2.9 \%$ of the paracasein matrix is hydrolysed in the first $15 \mathrm{~h}$ of Cantal cheese manufacture. Such a quantification of the early proteolysis in hard cheese varieties, including Cheddar, is not available to our knowledge. This NCN increase must likely result from both general proteolytic activity of residual chymosin and LAB lactocepin activities [43]. 
Because of the relatively low $\mathrm{pH}$ (around $5.0)$ and the duration $(15 \mathrm{~h})$, it is questionable that other proteinases such as indigenous or somatic cell plasmin play a major role in this early hydrolysis of paracasein matrix. Nevertheless, further work is required to identified casein substrates and enzymes implied in this early proteolysis, as previously done by Gagnaire et al. [17] in Emmental cheese making.

Differences in some compositional attributes were detected in the juices expressed from the matured $\left(\mathrm{T}_{14 \mathrm{~h}}\right)$ and salted $\left(\mathrm{T}_{15 \mathrm{~h}}\right)$ tomes (Tab. I). These differences likely resulted of the heterogeneity of the matured tome. Indeed, tomes obtained with curd particles of which temperature is $30^{\circ} \mathrm{C}$ are moved to a $19{ }^{\circ} \mathrm{C}$ acidification room. That induces an uneven cooling of the curd mass $\left(30{ }^{\circ} \mathrm{C}\right.$ in the core compared to $19^{\circ} \mathrm{C}$ at the surface) and consequently an acidification gradient across the cheese block and hence, a variation in the lactose, lactate, calcium and inorganic phosphate contents across the matured tome. Then milling of the matured tome and mixing with the salt reduced this heterogeneity and gives a homogeneous composition to the salted tome.

\subsection{Compositional analysis and biochemical indices during ripening of Cantal cheese}

During the first $3 \mathrm{~d}$ of the ripening period, some whey was drained of the salted tome. Consequently, total solids content increased to $595.8 \pm 8.6 \mathrm{~g} \cdot \mathrm{kg}^{-1}$ at $3 \mathrm{~d}$ and then to $602.9 \pm 5.3 \mathrm{~g} \cdot \mathrm{kg}^{-1}$ at $120 \mathrm{~d}$. Fat and ashes contents for the same ripening times were respectively $293.5 \pm 2.1 \mathrm{~g} \cdot \mathrm{kg}^{-1}$ and $296.8 \pm$ $5.3 \mathrm{~g} \cdot \mathrm{kg}^{-1} ; 44.4 \pm 2.5 \mathrm{~g} \cdot \mathrm{kg}^{-1}$ and $43.5 \pm$ $1.7 \mathrm{~g} \cdot \mathrm{kg}^{-1}$. Table II shows the changes in the compositional attributes determined in the juice expressed from the cheese at 3,30 , 60 and $120 \mathrm{~d}$ of ripening. Whereas the $\mathrm{pH}$ did not change drastically, a large increase in the Dornic acidity was observed over ripening time course. Plotting this acidity increase with the evolution of NPN values showed a high correlation coefficient $\left(\mathrm{R}^{2}=\right.$ 0.986) in agreement with previous observations on Cheddar [33] and on Emmental [28].
The residual lactose at demoulding $\left(\mathrm{T}_{3 \mathrm{~d}}\right)$ (1 to $17 \%$ of the initial milk lactose according to the trial) was slowly metabolised, mainly during the first $30 \mathrm{~d}$ of ripening. $\mathrm{Re}-$ sidual lactose in young cheese can induce a post-acidification and consequently modify the metabolism of the ripening ecosystem (LAB and NSLAB). Lactate content did not change a lot even after $60 \mathrm{~d}$ of ripening. The kinetics of citrate consumption differed from one batch to another during ripening. Citrate was slowly metabolised during ripening and it was not detectable after $120 \mathrm{~d}$ of ripening. These results are in line with the observations of Thomas [42] on Cheddar. The consumption of citrate likely results of the metabolism of facultative heterofermentative lactobacilli of the NSLAB flora as well as citrate-positive strains of lactococci (L. lactis subsp. lactis biovar diacetylactis, Leuconostoc sp.) and some yeasts [35].

Total Ca levels in the cheese were $17.6 \pm$ 1.6, $18.5 \pm 0.5,18.2 \pm 0.6$ and $17.4 \pm$ $0.5 \mathrm{~g} \cdot \mathrm{kg}^{-1}$ of water after $3,30,60$ and $120 \mathrm{~d}$ of ripening respectively. Soluble $\mathrm{Ca}$ was $6.8 \mathrm{~g} \cdot \mathrm{kg}^{-1}$ of water at the demoulding step $\left(\mathrm{T}_{3 \mathrm{~d}}\right)$ and $8.1 \mathrm{~g} \cdot \mathrm{kg}^{-1}$ of water after $120 \mathrm{~d}$ of ripening (Tab. II). Comparison of these two series of data showed that the proportion of $\mathrm{Ca}$ in the aqueous phase was maintained around $39 \%$ from salting until the 30th day of ripening. Then, likely due to the breakdown of the cheese matrix which allowed Ca release in the aqueous phase, the ratio increased to 0.43 and 0.46 at 60 and $120 \mathrm{~d}$ respectively. In contrast, the concentration of inorganic phosphate, in the juice was seen to decrease from 3 to $60 \mathrm{~d}(3.1 \pm 0.1$ to $1.8 \pm$ $0.1 \mathrm{~g} \cdot \mathrm{kg}^{-1}$ of water) and then to increase to $2.4 \pm 0.3 \mathrm{~g} \cdot \mathrm{kg}^{-1}$ of water by $120 \mathrm{~d}$. Total P levels in the cheese were $18.1 \pm 0.5,17.9 \pm$ $2.5,19.6 \pm 0.9$ and $21.7 \pm 2.7 \mathrm{~g} \cdot \mathrm{kg}^{-1}$ of water after 3, 30, 60 and $120 \mathrm{~d}$ of ripening respectively. As for $\mathrm{Ca}$, calculating the ratio of $\mathrm{P}$ in the juice to total $\mathrm{P}$ in cheese showed a decrease from 0.09 at demoulding $\left(\mathrm{T}_{3 \mathrm{~d}}\right)$ to 0.05 at $120 \mathrm{~d}$ of ripening. A similar decrease in the $\mathrm{P}$ content of juice was previously reported in Emmental cheese between brining and warm room ripening [38]. This decrease in soluble $\mathrm{P}$ may be due to the migration of $\mathrm{Ca}$ phosphate followed by a 
Table II. Changes in compositional and proteolysis attributes in juices and lipolysis in cheeses during ripening of Cantal cheeses. Values are means and standard deviations of two or three determinations for three cheese trials.

\begin{tabular}{|c|c|c|c|c|c|}
\hline \multirow{2}{*}{$\begin{array}{l}\text { Content } \\
\left(\mathrm{g} \cdot \mathrm{kg}^{-1} \text { water }\right)\end{array}$} & \multicolumn{4}{|c|}{ Ripening steps } & \multirow{2}{*}{$P^{\mathrm{c}}$} \\
\hline & $3 \mathrm{~d}$ & $30 \mathrm{~d}$ & $60 \mathrm{~d}$ & $120 \mathrm{~d}$ & \\
\hline $\mathrm{pH}$ & $5.09 \pm 0.01$ & $5.12 \pm 0.01$ & $5.15 \pm 0.06$ & $5.21 \pm 0.06$ & $* \pi$ \\
\hline Acidity $\left(\right.$ Dornic $^{\circ}$ ) & $97 \pm 5$ & $111 \pm 3$ & $134 \pm 8$ & $171 \pm 4$ & *** オ \\
\hline Total solids & $150.2 \pm 4.7$ & $181.3 \pm 3.5$ & $213.7 \pm 0.3$ & $260.6 \pm 1.7$ & $* * * \pi$ \\
\hline Ash & $78.9 \pm 4.7$ & $79.1 \pm 6.3$ & $84.4 \pm 4.1$ & $88.7 \pm 5.0$ & *** 入 \\
\hline \multicolumn{6}{|l|}{$\overline{\text { Carbon sources }}$} \\
\hline Lactose & $5.3 \pm 2.3$ & $0.9 \pm 1.5$ & $<0.1$ & $<0.1$ & - \\
\hline Lactates & $48.8 \pm 1.8$ & $50.3 \pm 1.6$ & $50.5 \pm 2.1$ & $49.3 \pm 4.7$ & NS \\
\hline Citrate & $0.9 \pm 1.3$ & $0.7 \pm 1.2$ & $0.5 \pm 0.8$ & $<0.1$ & NS \\
\hline \multicolumn{6}{|l|}{ Minerals } \\
\hline Sodium & $21.7 \pm 2.1$ & $21.1 \pm 2.1$ & $22.8 \pm 1.4$ & $24.8 \pm 2.4$ & $* \pi$ \\
\hline Chlorides & $37.8 \pm 4.8$ & $37.3 \pm 3.6$ & $39.8 \pm 3.5$ & $43.0 \pm 4.3$ & NS \\
\hline Potassium & $2.6 \pm 0.2$ & $2.6 \pm 0.2$ & $2.8 \pm 0.2$ & $3.2 \pm 0.1$ & NS \\
\hline Calcium & $6.8 \pm 0.6$ & $7.3 \pm 0.3$ & $7.8 \pm 0.2$ & $8.1 \pm 0.5$ & NS \\
\hline Inorganic phosphate & $3.1 \pm 0.1$ & $2.0 \pm 0.1$ & $1.8 \pm 0.1$ & $2.4 \pm 0.3$ & $* * *$ \\
\hline \multicolumn{6}{|l|}{ Nitrogen compounds } \\
\hline Total nitrogen & $36.2 \pm 6.2$ & $70.5 \pm 8.2$ & $96.8 \pm 4.0$ & $140.9 \pm 5.7$ & *** 入 \\
\hline Non caseinic nitrogen & $31.0 \pm 5.0$ & $65.6 \pm 7.6$ & $91.7 \pm 3.3$ & $135.8 \pm 6.0$ & $* * * \pi$ \\
\hline Non proteic nitrogen & $18.6 \pm 4.2$ & $43.4 \pm 4.0$ & $65.4 \pm 3.8$ & $107.7 \pm 4.9$ & $* * * \pi$ \\
\hline Free amino acids & $3.7 \pm 1.7$ & $12.4 \pm 2.6$ & $22.2 \pm 2.0$ & $43.4 \pm 2.6$ & $* * * \pi$ \\
\hline \multicolumn{6}{|c|}{ Free fatty acids (g-kg-1 cheese) } \\
\hline$\Sigma(\mathrm{C} 4: 0-\mathrm{C} 18: 3)$ & $\mathrm{ND}^{\mathrm{b}}$ & ND & $1.98 \pm 0.52$ & $2.12 \pm 0.57$ & $* \pi$ \\
\hline Propanoic acid & ND & ND & $1.10 \pm 0.35$ & $1.40 \pm 0.51$ & NS \\
\hline Ethanoic acid & ND & ND & $0.01 \pm 0.01$ & $0.02 \pm 0.03$ & NS \\
\hline Methylbutanoic acid & ND & ND & $0.01 \pm 0.01$ & $0.01 \pm 0.01$ & NS \\
\hline$\Sigma(\mathrm{C} 4: 0-\mathrm{C} 8: 0)$ & ND & ND & $0.10 \pm 0.02$ & $0.14 \pm 0.03$ & NS \\
\hline$\Sigma(\mathrm{C} 10: 0-\mathrm{C} 14: 0)$ & ND & ND & $0.41 \pm 0.10$ & $0.45 \pm 0.11$ & $* \pi$ \\
\hline$\Sigma(\mathrm{C} 16: 0-\mathrm{C} 18: 3)$ & ND & ND & $1.47 \pm 0.40$ & $1.54 \pm 0.44$ & $* \pi$ \\
\hline
\end{tabular}

a Results are expressed per $\mathrm{kg}$ of water in order to allow direct comparisons of solubilised compounds over the ripening.

b ND: not determined.

c Results of the analysis of variance: probability of F-test; NS not significant; $* 0.05 \leq P<0.01$; $* * 0.01 \leq P<0.001 ; * * * P \leq 0.001 ;-$ : ANOVA not performed. The direction of variation during ripening is symbolized by an arrow. 


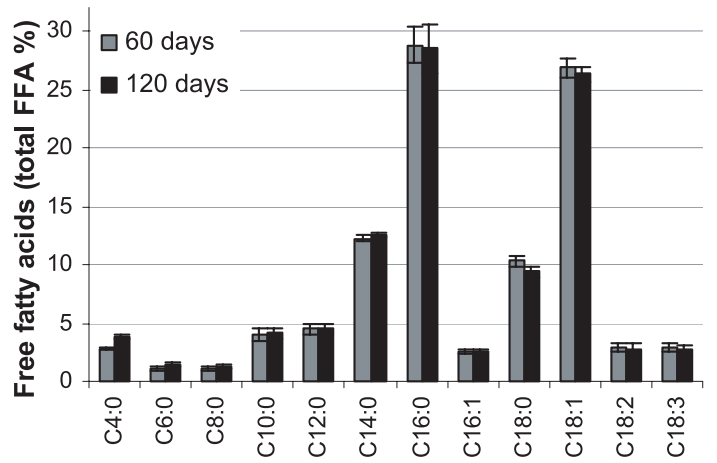

Figure 4. Relative percentages of free fatty acids (FFA) contents at 60 and $120 \mathrm{~d}$ of ripening of Cantal cheeses. Error-bars show standard deviation of 6 determinations ( 2 replicates $\times 3$ trials).

deposit to the cheese surface. Further work is required to fully understand the kinetics of $\mathrm{P}$ ion in both cheese and juice of Cantal during manufacture and ripening.

The TN content of the cheese aqueous phase was multiplied by 3.9 during ripening for reaching $140.9 \mathrm{~g} \cdot \mathrm{kg}^{-1}$ of water at $120 \mathrm{~d}$. Levels of NCN and NPN in cheese aqueous phase expressed a percentage of TN increased respectively from 85.6 and $51.4 \%$ at $3 \mathrm{~d}$ to 96.4 and $76.4 \%$ at $120 \mathrm{~d}$ (Tab. II). Using values of TN and NCN in cheese and the homologous values in juice, proteolysis of cheese paracasein matrix was calculated to increase to $4.4 \%$ at $3 \mathrm{~d}, 10.1 \%$ at $30 \mathrm{~d}$, $14 \%$ at $60 \mathrm{~d}$ and $20.9 \%$ at $120 \mathrm{~d}$ of ripening. The urea-PAGE electrophoresis patterns (data not shown) indicated a fast hydrolysis of $\alpha s_{1}$-casein with the concomitant appearance of $\alpha_{\mathrm{S} 1-1}$ and a slow degradation of $\beta$ casein with appearance of $\gamma$-casein bands similar to that observed in Cheddar [15] and likely originated by activity of plasmintype enzymes (endogenous and from somatic cells) on $\beta$-casein. The peptidic profiles obtained from RP-HPLC became more complex as ripening progressed, with a large increase of small hydrophilic peptides by the end of ripening (data not shown).

Total free amino acids (FAA) content in the cheese aqueous phase increased linearly from $10.2 \%$ of aqueous phase $\mathrm{TN}$ at $3 \mathrm{~d}$ to $30.8 \%$ at $120 \mathrm{~d}$ (Tab. II). These results are in the same range as those previously reported for $120 \mathrm{~d}$ aged Cantal [8] and $90 \mathrm{~d}$ old Cheddar aqueous phase [36], i.e. respectively 32.5 and $29.1 \mathrm{~g} \cdot \mathrm{kg}^{-1}$ water of total FAA in cheese aqueous phase. The level of most of individual FAA increased as globally with the time course of ripening. Nevertheless, a deeper survey of the results obtained with the three trials showed a 2 to 5 times variation for the contents in Arg, Pro, Ser, Cit and Homocys despite a similar amount of total FAA. These variations could likely result in some differences in the enzymatic activities as well as the metabolism of the micro-organisms present in the raw milk flora such as release of Pro, transformation of Arg in Cit and Orn or Ser to pyruvate. As said before, further work is required to elucidate the proteolytic mechanisms coming both from the milk endogenous enzymes and from the metabolism of the raw milk and added microbial ecosystem.

\subsection{Survey of lipolysis}

Individual FFA were measured at 60 and $120 \mathrm{~d}$ of ripening. The concentration of total FFA (Tab. II) and most of the individual FFA (Fig. 4) varied poorly between 60 and $120 \mathrm{~d}$ of ripening, indicating that lipolysis had occurred either during manufacture or in the early ripening, as was recently reported in Cheddar cheese [20]. Only the concentrations of butanoic and hexanoic acids significantly increased $(+43 \%)$ after $60 \mathrm{~d}$ of ripening. By $120 \mathrm{~d}$ Cantal cheeses contained a total of $2.12 \pm 0.57 \mathrm{~g} \cdot \mathrm{kg}^{-1}$ of FFA (C4-C18:3). This value corresponds to a low level of lipolysis $(0.7 \pm 0.2 \%$ of fat $)$, 
similar to previous observations in Emmental [26] and Cheddar cheeses $(0.5-1 \%)$ [20]. In spite of this low level of lipolysis detected in Cantal cheese, the concentrations of FFA (in particular short and medium chain FFA) are considered to play a significant role in flavor development and perception as shown in both Emmental and Cheddar where short to medium-chain FFAs ( $<12$ carbon atoms), and in particular butanoic acid, impart a "cheesy", "pungent", "fruity", and "rancid" flavor [1]. Palmitic (C16:0) and oleic (C18:1) acids were the main FFA detected in Cantal cheese, similar to that reported in bovine milk (Fig. 4).

\subsection{Volatile analysis}

Neutral volatile compounds were determined at 3, 30, 60, and $120 \mathrm{~d}$ of ripening (Tab. III). Thirty two compounds were identified in the headspace of Cantal cheese aqueous phase and have been previously reported in dairy products [29], and most of them in matured Cantal cheese [8]. Ethanol was the main compound detected by the headspace technique used and represented about $66 \%$ (based on peak areas) of total volatiles detected from 3 to $60 \mathrm{~d}$ of ripening. Ethanol concentrations did not vary over the ripening period and the values found in ripened Cantal cheeses $\left(43 \pm 7 \mathrm{mg} \cdot \mathrm{kg}^{-1}\right.$, quantified by an enzymatic method) were in the range previously reported for Cantal cheese $(30$ and $85 \mathrm{mg} \cdot \mathrm{kg}^{-1}$ ) [8]. Ethanol is thought to be produced by yeasts, heterofermentative bacteria such as leuconostocs, or even homofermentative lactic acid bacteria such as lactococci and thermophilic lactobacilli [21]. Ethanol, as with other cheese alcohols, is considered to have no direct impact on cheese flavor. However, the level of ethanol in cheese is a limiting factor in the formation of ethyl esters in Cheddar and Emmental cheese [41, 44], which are considered as flavor active compounds in various cheeses [7]. The concentrations of two ethyl esters, ethyl butanoate and ethyl hexanoate, significantly increased during the ripening (Tab. III). By $120 \mathrm{~d}$, the profiles of head space volatiles were characterized by the presence of two C4-compounds, 2-butanone and 2-butanol, which accumulated in cheese and accounted for about $60 \%$ of total volatiles. The C4compounds are thought to be products of citrate metabolism. Citrate can be first converted to 2,3-butanediol (diacetyl), which is then reduced to acetoin and 2,3butanediol by mesophilic starters in Cheddar cheese [44]. 2,3-Butanediol can be further converted to 2-butanone and reduced to form 2-butanol by some nonstarter Lactobacillus species [23], such as L. plantarum and L. brevis species. L. plantarum was shown to be present by PCR-TTGE in the Cantal at $60 \mathrm{~d}$ of ripening (see Fig. 1). Diacetyl was detected at the first stages of cheese manufacture, its concentration decreasing throughout the ripening (Tab. III) and was not detected at $120 \mathrm{~d}$ in two cheeses out of three, as previously reported in matured Cantal cheese [8]. The intermediary products acetoin and 2,3-butanediol were not detected in Cantal cheese, whereas the more reduced product, 2-butanol appeared after 60-120 d of ripening. These changes in C4compounds over ripening of Cantal cheese appear similar to observations in Cheddar cheese [2]. Similarly, the secondary alcohol 2-pentanol, produced from the reduction of 2-heptanone, also appeared at the latest stages of ripening in the three Cantal cheese batches, with however, great differences in concentrations in the three batches. This is likely due to differences in the rate of reduction of ketones to secondary alcohols, which can result from the activity of raw milk cheese microflora [3]. For example, the concentrations of 2-butanol and 2pentanol were about 30 and 10 fold higher, respectively, in one of the three cheese trials, compared to the two others. 2Propanol also appeared sooner in this batch. These differences in the kinetics of volatile formation explained the high values of standard deviation for some volatiles (Tab. III). Nevertheless, similar trends were observed in the three trials. 1-Propanol and acetaldehyde were seen to significantly increase between 60 and $120 \mathrm{~d}$ of ripening. In contrast, the concentrations of most aldehydes (pentanal, octanal, and nonanal) 
Table III. Changes in neutral volatile compounds in Cantal cheese aqueous phase analyzed by head space GC-MS at four stages of ripening.

\begin{tabular}{|c|c|c|c|c|c|c|c|}
\hline \multirow[t]{2}{*}{$\mathrm{RT}^{\mathrm{a}}$} & \multirow[t]{2}{*}{ Compound ${ }^{\mathrm{b}}$} & \multicolumn{4}{|c|}{$\mathrm{TIC}$ areas (arbitrary units) ${ }^{\mathrm{c}}$} & \multirow[t]{2}{*}{ Stat. ${ }^{d}$} & \multirow[t]{2}{*}{ Ref. $^{\mathrm{e}}$} \\
\hline & & $3 \mathrm{~d}$ & $30 \mathrm{~d}$ & $60 \mathrm{~d}$ & $120 \mathrm{~d}$ & & \\
\hline 2.96 & ethanal (acetaldehyde) & $2.1 a \pm 1.7$ & $0.7 a \pm 0.3$ & $2.0 a \pm 1.5$ & $7.3 b \pm 3.3$ & $0.02 \pi$ & [1] \\
\hline 4.51 & ethanol & $4245 \pm 400$ & $3943 \pm 862$ & $4439 \pm 995$ & $4467 \pm 1851$ & - & {$[1]$} \\
\hline 4.76 & 2-propanone (acetone) & $390 \pm 159$ & $504 \pm 121$ & $330 \pm 193$ & $1682 \pm 1955$ & - & {$[1]$} \\
\hline 5.33 & 2-propanol (isopropyl alcohol) & $11.3 \pm 9.9$ & $26.0 \pm 37.3$ & $131 \pm 213$ & $160 \pm 124$ & - & [2] \\
\hline 6.06 & 2-methyl-2-propanol* & $9.9 \pm 8.6$ & $4.1 \pm 7.1$ & $1.1 \pm 1.9$ & ND & - & [3] \\
\hline 6.71 & 2-methyl-propanal* & $3.3 \pm 5.6$ & ND & ND & ND & - & [2] \\
\hline 7.11 & 1-propanol & $18 a \pm 9.7$ & $25.0 a \pm 12.7$ & $59.5 a \pm 12.0$ & $258 b \pm 104$ & $0.004 \pi$ & [1] \\
\hline 8.13 & 2,3-butanedione (diacetyl) & $735 a \pm 105$ & $295 b \pm 238$ & $48 b c \pm 44$ & $11 c \pm 20$ & لا $>0.001$ & {$[2]$} \\
\hline 8.24 & 2-butanone & $42.7 a \pm 73.9$ & $1299 a \pm 971$ & $2063 a \pm 1545$ & $4769 b \pm 53$ & $0.005 \pi$ & [1] \\
\hline 8.56 & 2-butanol & $2.0 a \pm 3.4$ & $12.7 a \pm 17.9$ & $60 a \pm 46$ & $486 b \pm 309$ & $0.04 \pi$ & {$[1]$} \\
\hline 8.80 & ethyl acetate & $11.1 \pm 15.4$ & $14.2 \pm 9.7$ & $5.9 \pm 8.3$ & $11.1 \pm 9.6$ & - & {$[2]$} \\
\hline 9.54 & 2-methyl-1-propanol & $24.9 \pm 24.3$ & $26.6 \pm 21.5$ & $12.4 \pm 2.8$ & $12.9 \pm 1.4$ & - & {$[1]$} \\
\hline 10.61 & 3-methylbutanal & $12.2 \pm 13.6$ & $15.7 \pm 13.4$ & $11.3 \pm 7.2$ & $16.4 \pm 11.3$ & - & {$[1]$} \\
\hline 10.86 & 1-butanol & $1.3 \pm 0.2$ & $2.1 \pm 0.9$ & $8.9 \pm 3.8$ & $31.8 \pm 38.7$ & - & [1] \\
\hline 11.71 & 2-pentanone & $3.0 a \pm 1.6$ & $8.9 a b \pm 3.3$ & $19.8 c \pm 6.6$ & $16.5 b c \pm 6.5$ & $0.07 \pi$ & [1] \\
\hline 11.80 & heptane & $4.8 \pm 2.2$ & $3.0 \pm 1.6$ & $5.1 \pm 4.6$ & $4.2 \pm 3.4$ & - & [3] \\
\hline 12.17 & pentanal & $3.0 b \pm 3.0$ & $0.8 a \pm 0.7$ & ND & ND & لا 0.14 & [3] \\
\hline 12.22 & 2-pentanol & ND & ND & $1.1 \pm 0.1$ & $1.5 \pm 0.4$ & $0.004 \pi$ & [1] \\
\hline 13.48 & 3-methyl-1-butanol & $78.0 \pm 88.1$ & $89.0 \pm 82.9$ & $40.1 \pm 14.0$ & $39.7 \pm 14.0$ & - & [1] \\
\hline 13.63 & 2-methyl-1-butanol & $8.6 \pm 9.5$ & $9.9 \pm 9.5$ & $4.7 \pm 2.0$ & $3.0 \pm 1.6$ & - & [1] \\
\hline 14.06 & disulfide dimethyl & $2.4 \pm 0.4$ & $2.0 \pm 0.7$ & $9.4 \pm 13.0$ & $2.3 \pm 0.5$ & - & [1] \\
\hline 14.13 & 3-methyl-2-pentanone & $0.0 a$ & $2.3 \pm 0.8 a b$ & $1.2 a b \pm 1.0$ & $1.4 b \pm 0.4$ & $0.02 \pi$ & [1] \\
\hline 14.56 & 1-pentanol & $5.3 \pm 3.0$ & $2.5 \pm 0.1$ & $2.3 \pm 0.2$ & $1.4 \pm 0.4$ & - & [1] \\
\hline 15.62 & ethyl butanoate & $0.3 a \pm 0.4$ & $0.7 a b \pm 0.3$ & $1.3 a b \pm 0.5$ & $2.5 b \pm 2.0$ & $0.22 \pi$ & [1] \\
\hline 15.79 & hexanal & $8.3 \pm 10.8$ & $1.3 \pm 0.2$ & $0.9 \pm 0.4$ & $0.5 \pm 0.2$ & - & [2] \\
\hline 18.52 & 2-heptanone & $1.4 \pm 1.1$ & $2.2 \pm 0.8$ & $2.8 \pm 0.5$ & $3.4 \pm 1.3$ & - & [1] \\
\hline 18.78 & 2-heptanol & ND & ND & $0.5 \pm 0.3$ & $0.5 \pm 0.1$ & $0.18 \pi$ & {$[1]$} \\
\hline 18.93 & heptanal & $2.6 \pm 3.5$ & $0.3 \pm 0.3$ & $0.2 \pm 0.2$ & $0.2 \pm 0.2$ & - & [1] \\
\hline
\end{tabular}


Table III. Continued.

\begin{tabular}{|c|c|c|c|c|c|c|c|}
\hline \multirow[t]{2}{*}{$\mathrm{RT}^{\mathrm{a}}$} & \multirow[t]{2}{*}{ Compound ${ }^{b}$} & \multicolumn{4}{|c|}{$\mathrm{TIC}$ areas (arbitrary units) ${ }^{\mathrm{c}}$} & \multirow[t]{2}{*}{ Stat. $^{\mathrm{d}}$} & \multirow[t]{2}{*}{ Ref.e } \\
\hline & & $3 \mathrm{~d}$ & $30 \mathrm{~d}$ & $60 \mathrm{~d}$ & $120 \mathrm{~d}$ & & \\
\hline 21.34 & ethyl hexanoate & $0.3 a \pm 0.3$ & $0.5 a b \pm 0.7$ & $0.6 a b \pm 0.5$ & $0.8 b \pm 0.7$ & $0.01 \pi$ & [1] \\
\hline 21.67 & octanal & $1.1 a \pm 0.5$ & $0.7 a b \pm 0.2$ & $0.5 a b \pm 0.8$ & $0.2 b \pm 0.3$ & 0.22 ע & [1] \\
\hline 23.48 & 2-nonanone & $0.4 \pm 0.3$ & $2.5 \pm 2.1$ & $2.8 \pm 1.9$ & $2.2 \pm 2.2$ & - & [1] \\
\hline 23.78 & nonanal* & $1.5 a \pm 0.6$ & $1.0 a \pm 0.4$ & $0.9 a \pm 0.4$ & $0.2 b \pm 0.3$ & ע 0.03 & [1] \\
\hline
\end{tabular}

a RT: retention time in GC-MS.

b Compounds showing significant changes in concentration during the ripening are in bold. Compounds marked with * were tentatively identified by comparison of mass spectral data with those of NIST 75K database.

c Volatiles were quantified by total ion current (TIC) excepted for acetaldehyde, for which the fragment 29 was used. Results are means of six values (two determinations $\times$ three Cantal cheese batches), except for 2-butanol and 2-pentanol, were only two batches were considered (see text). Values in the same raw with the same letter do not significantly differ by LSD test $(\alpha<0.05)$. ND: not detected.

$\mathrm{d} P$-values of the ANOVA are given for compounds showing significant differences of concentration by LSD test $(\alpha<0.05)$. The direction of variation during ripening is symbolized by an arrow.

e References: [1], ripened Cantal [2, 8], Cheddar [3], other cheeses [29].

decreased, as previously reported for other hard cheeses such as Cheddar [12] and Emmental cheeses [40]. Cantal cheeses also contained short-chain acids (Tab. II) which are likely to originate from the fermentation of lactate and/or the catabolism of amino acids [30]. In addition to the other shortchain FFAs derived from fat lipolysis, these acids are common odor-active compounds in cheese and could be involved in Cantal flavour [7].

\subsection{Microstructural analysis}

Figure 5 shows micrographs of the microstructure of Cantal cheese at different stages of manufacture and ripening. In the matured tome (Fig. 5A), the supramolecular organisation of the fat was seen as many inclusions with a range of different sizes and shapes (colored in red), which appeared to stand out along the direction of pressing. Thus, fat was not organised as spherical globules as determined in cheese milk. The membrane of the milk fat globules (MFGM) may have been disrupted during pre-pressing and/or during the six consecutive pressing stages $(90 \mathrm{~min})$, leading to the formation of "free fat" (fat not protected by the MFGM). These results are similar to those previously reported in Cheddar [22] and Emmental cheese [25], where pressing was shown to be the main destabilising stage for the supramolecular organisation of fat globules during the manufacture. Pockets of whey, that appear as black areas on the micrograph, were also observed in the microstructure of the matured tome. After milling and dry-salting, the inclusions of fat appeared to be larger than in the matured tome (Fig. 5B). Free fat, which corresponded to inclusions of 40 to $80 \mu \mathrm{m}$, may be formed as a result of the high increase in osmotic pressure due to salting. Residual fat globules, 5-10 $\mu \mathrm{m}$, were also observed. Figure 5C shows the microstructure of Cantal cheese after the last pressing stage $\left(\mathrm{T}_{3 \mathrm{~d}}\right)$. As for Figure 5A, the longitudinal orientation of both the fat and protein network was clearly visible. Furthermore, the presence of curd grain junctions was also observed in Figures 5C and 5E (black arrows). As previously observed using CLSM, the grain junctions contained a higher level of protein and less fat than in the inner region of the curd grains [26]. Figures 5D to $5 \mathrm{~F}$ show the changes of the Cantal cheese microstructure during ripening. After $120 \mathrm{~d}$ of ripening (Fig. 5F), the fluorescent dye used to stain the protein network was less 

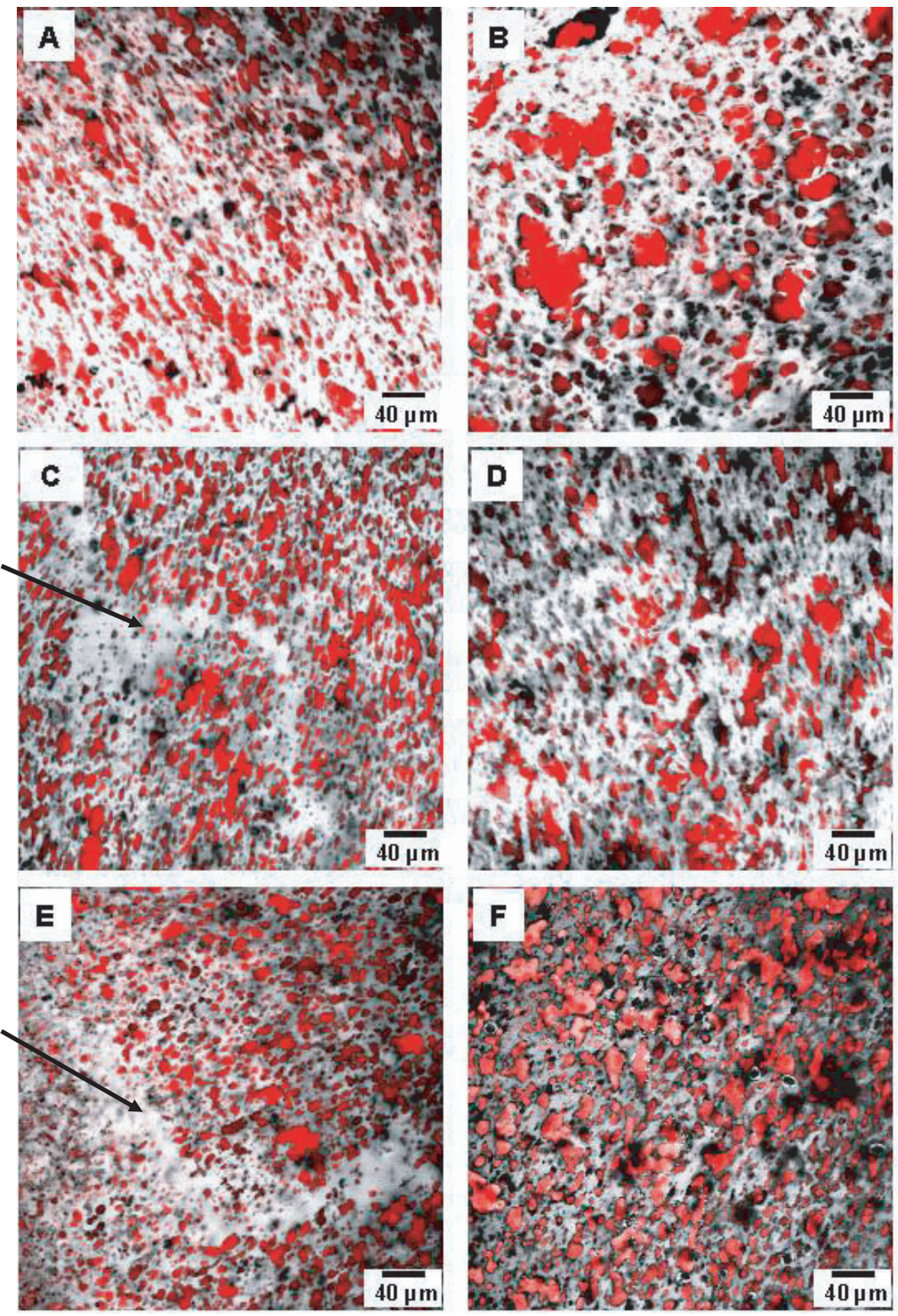

Figure 5. Confocal laser scanning micrographs corresponding to the microstructure at different stages of manufacture and ripening of Cantal cheeses : (A) matured tome, (B) salted tome, (C) $3 \mathrm{~d}$ cheese, (D) $30 \mathrm{~d}$ cheese, (E) $60 \mathrm{~d}$ cheese and (F) $120 \mathrm{~d}$ cheese. Fat appears in red, proteins in white. 
efficient, i.e. less intensity of fluorescence was detected. This may be related to the higher level of proteolysis detected at the end of ripening.

The presence of large inclusions of free fat observed in situ, right after acidification $\left(\mathrm{T}_{14 \mathrm{~h}}\right)$ shows that cheese fat should easily be extracted from cheese at this stage. However, the yields of oil extracted varied from $0.5-0.8 \mathrm{~mL}$ oil per $100 \mathrm{~g}$ cheese after acidification, $5.8 \%$ at demoulding and about $11.3 \%$ after $30 \mathrm{~d}$ of ripening. This indicates that other factors, such as changes in the structure of the paracasein matrix are involved in the extractability of oil (and aqueous phase).

\section{CONCLUSION}

This work represents the first kinetic biochemical, microbiological, and structural study reported on the manufacture and ripening of raw milk Cantal cheese. From the obtained results, manufacturers have knowledge of the final cheese characteristics influenced by either added starters ecosystem or by the process parameters and could now lever these parameters up to modify the final cheese characteristics. The controlled manufacturing conditions and the use of a complex mixture of starters led to very similar cheeses. Indeed, the three cheese trials had very similar compositional characteristics, extent and pattern of proteolysis and similar changes in neutral volatiles compounds throughout ripening. Nevertheless, if the cheese microflora was dominated by the starter populations, the three cheese trials differed by some microbiological and biochemical characteristics. Populations of yeasts brought by the used raw milk achieved after acidification $\left(\mathrm{T}_{14 \mathrm{~h}}\right)$ varied by $4 \log _{10} \mathrm{cfu} \cdot \mathrm{g}^{-1}$ (from 5.0 to 9.0 ), while the populations of facultative heterofermentative lactobacilli varied from 6.5 to $7.4 \log _{10} \mathrm{cfu} \cdot \mathrm{g}^{-1}$ at the same stage. These differences in populations may originate some of the biochemical differences observed between the three cheese trials, regarding in particular the rates of citrate utilization, and the content of some amino acids like Arg, Cit and Ser. The variation in non-starter microflora may also, directly or indirectly, be the source of the differences in the kinetics of acidification and lactococci lysis, as well as in the concentrations of some volatiles like secondary alcohols. Moreover, native milk microflora is likely to have influenced the sensory characteristics of the cheese, as has been shown for many raw milk cheeses [3]. In contrast, some of the differences observed in cheese composition are more likely due to variations in milk composition, rather than milk native microflora. The extent of lipolysis, for example, differed by up to $40 \%$ between the three cheese trials, and may be related to the levels of FFA in the raw milk, as recently shown in Cheddar cheese [20]. The presence in raw milk of compounds inhibiting and/or stimulating the activity of lactic acid bacteria could also have influenced the rate of acidification [11].

The Cantal cheesemaking process is similar to Cheddar cheese. Both processes include in particular a milling and a dry salting step, which results in cheese with a homogeneous composition. Both cheese varieties have a similar composition, extent and pattern of proteolysis (as shown by urea-PAGE profiles and FAA contents). However, the higher temperature (38$39^{\circ} \mathrm{C}$ ) and the starter used in Cheddar cheese manufacture results in the acceleration of the acidification rate and of the consequent syneresis [24], compared to that of Cantal cheese, where acidification takes place over a much longer period of time $(\sim 14 \mathrm{~h})$.

The observations made on the organisation of milk fat also suggests that more work is needed to understand how mechanical treatments applied during milling and pressing induce the disruption of the native fat globule membrane and what forces cause the large inclusions of fat as observed by CLSM. The localisation of bacterial colonies observed at the fat/paracasein interface highlights the fact that further study is required to understand the interactions that exist between bacteria and their environment in situ in cheese and their possible consequence on the microheterogeneity of cheese. 
Acknowledgements: We are indebted to the society $3 \mathrm{~A}$ and especially to its subsidiary LFO for their financial and technical support. We particularly wish to express our gratitude to $\mathrm{M}$. Place and A. Vigier for fruitful discussion and pertinent observations. The authors would also like to thank Dr. J.A. Hannon for critical reading of the manuscript and improving the English writing.

\section{REFERENCES}

[1] Aston J.W., Dulley J.R., Cheddar cheese flavour, Aust. J. Dairy Technol. 37 (1982) 5964.

[2] Barlow I., Lloyd G.T., Ramshaw E.H., Miller A.J., Mc Cabe G.P., Mc Cabe L., Correlations and changes in flavour and chemical parameters of Cheddar cheese during maturation, Aust. J. Dairy Technol. 44 (1989) 718.

[3] Beuvier E., Buchin S., Raw milk cheeses, in: Fox P.F., McSweeney P.L.H., Cogan T.M., Guinee T.P. (Eds.), Cheese: Chemistry, Physics and Microbiology, Elsevier, London, UK, 2004, pp. 319-345.

[4] Callon C., Millet L., Montel M.C., Diversity of lactic acid bacteria isolated from AOC Salers cheese, J. Dairy Res. 71 (2004) 231244.

[5] CNIEL, in: L'économie laitière en chiffres, Paris, France, 2004.

[6] Cogan T.M., O'Dowd M., Mellerick D., Effects of $\mathrm{pH}$ and sugar on acetone production from citrate by Leuconostoc lactis, Appl. Environ. Microbiol. 41 (1981) $1-9$.

[7] Curioni P.M.G., Bosset J.O., Key odorants in various cheese types as determined by gas chromatography-olfactometry, Int. Dairy J. 12 (2002) 959-984.

[8] De Freitas I., Pinon N., Lopez C., Thierry A., Maubois J.-L., Lortal S., Microstructure, physicochemistry, microbial populations and aroma compounds of ripened Cantal cheeses, Lait 85 (2005) 453-468.

[9] De Jong C., Badings H.T., Determination of free fatty acids in milk and cheese. Procedures for extraction clean up and capillary gas chromatographic analysis, J. High Resol. Chromatogr. 13 (1990) 94-98.

[10] Desmasures N., Opportune W., Gueguen M., Lactococcus spp., yeasts and Pseudomonas spp. on teats and udders of milking cows as potential sources of milk contamination, Int. Dairy J. 7 (1997) 643-646.
[11] Desmazeaud M.J., de Roissart H., Métabolisme général des bactéries lactiques, in: de Roissart H., Luquet F.M. (Eds.), Bactéries lactiques, Lorica, Uriage, France, 1994, pp. 169-207.

[12] Dimos A., Urbach G.E., Miller A.J., Changes in flavour and volatiles of full-fat and reduced-fat Cheddar cheeses during maturation, Int. Dairy J. 6 (1996) 981-995.

[13] Duthoit F., Godon J.J., Montel M.C., Bacterial community dynamics during production of Registered Designation of Origin Salers cheese as evaluated by 16 S rRNA gene Single-Strand Conformation Polymorphism analysis, Appl. Environ. Microbiol. 69 (2003) 3840-3848.

[14] Ercolini D., PCR-DGGE fingerprinting: novel strategies for detection of microbes in food, J. Microbiol. Meth. 56 (2004) 297-314.

[15] Fox P.F., McSweeney P.L.H., Proteolysis in cheese during ripening, Food Rev. Int. 12 (1996) 457-509.

[16] Fox P.F., McSweeney P.L.H., Lynch C.M., Significance of non-starter lactic acid bacteria in cheddar cheese, Aust. J. Dairy Technol. 53 (1998) 83-89.

[17] Gagnaire V., Mollé D., Herrouin M., Léonil J., Peptides identified during Emmental cheese ripening: origin and proteolytic systems involved, J. Agric. Food Chem. 49 (2001) 4402-4413.

[18] Guinee T.P., Salting and the role of salt in cheese, Int. J. Dairy Technol. 57 (2004) 99109.

[19] Hannon J.A., Deutsch S.M., Madec M.N., Gassi J.Y., Chapot-Chartier M.P., Lortal S., Lysis of starters in UF cheeses: Behaviour of mesophilic lactococci and thermophilic lactobacilli, Int. Dairy J. 16 (2006) 324-334.

[20] Hickey D.K., Kilcawley K.N., Beresford T.P., Sheehan E.M., Wilkinson M.G., The influence of a seasonal milk supply on the biochemical and sensory properties of Cheddar cheese, Int. Dairy J. 16 (2006) 679-690.

[21] Imhof R., Bosset J.O., Relationships between micro-organisms and formation of aroma compounds in fermented dairy products Review, Z. Lebensm. Unters. Forsch. 198 (1994) 267-276.

[22] Kaláb M., Emmons D.B., Milk gel structure. IX. Microstructure of Cheddared curd, Milchwissenschaft 33 (1978) 670-673.

[23] Keen A.R., Walker N.J., Peberdy M.F., The formation of 2-butanone and 2-butanol in Cheddar cheese, J. Dairy Res. 41 (1974) 249257. 
[24] Lawrence R.C., Gilles J., Creamer L.K., Crow V.L., Heap H.A., Honoré C.G., Johnston K.A., Samal P.K., Cheddar cheese and related dry-salted cheese varieties, in: Fox P.F., McSweeney P.L.H., Cogan T.M., Guinee T.P. (Eds), Cheese: Chemistry, Physics and Microbiology, Elsevier, London, 2004, pp. 71-102.

[25] Lopez C., Maillard M.B., Briard-Bion V., Camier B., Hannon J.A., Lipolysis during ripening of Emmental cheese considering organisation of fat and preferential localisation of bacteria, J. Agric. Food Chem. 54 (2006) 5855-5867.

[26] Lopez C., Camier B., Gassi J.Y., Development of the milk fat structure during the manufacture and ripening of Emmental cheese observed by confocal laser scanning microscopy, Int. Dairy J. 17 (2007) 235-247.

[27] Lortal S., Chapot-Chartier M.P., Role, mechanisms and control of lactic acid bacteria lysis in cheese, Int. Dairy J. 15 (2005) 857-871.

[28] Lucey J.A., Gorry C., Fox P.F., Changes in the acid-base buffering curves during the ripening of Emmental cheese, Milchwissenschaft 48 (1993) 183-186.

[29] Maarse H., Visscher C.A., Willemsens L.C., Nijssen L.M., Boelens M.H., in: Volatile Compounds in Food: qualitative and quantitative data, TNO Nutrition and Food Research, Zeist, The Netherlands, 1994.

[30] McSweeney P.L.H., Sousa M.J., Biochemical pathways for the production of flavour compounds in cheeses during ripening: a review, Lait 80 (2000) 293-324.

[31] Michalski M.C., Briard V., Michel F., Optical parameters of milk fat globules for laser light scattering measurements, Lait 81 (2001) 787-796.

[32] Mocquot G., Étude sur l'eau liée des fromages, Lait 27 (1947) 576-595.

[33] Nelson B.K., Barbano D.M., Yield and aging of Cheddar cheeses manufactured from milks with different milk serum protein contents, J. Dairy Sci. 88 (2005) 4183-4194.

[34] Reinheimer J.A., Renzulli P.M., Rubiolo A.C., Bailo N.B., Binetti A.G., Effects of sodium chloride and potassium chloride on growth and acid production in thermophilic lactic acid bacteria, Microbiol. Alim. Nutri. 15 (1997) 7-15.
[35] Roostita R., Fleet G.H., The occurrence and growth of yeasts in Camembert and Blue-veined cheeses, Int. J. Food Microbiol. 28 (1996) 393-404.

[36] Roy D., Pitre M., Blanchette L., Savoie L., Belanger G., Ward P., Maubois J.-L., Monitoring proteolysis and cheese juice composition during ripening of Cheddar cheese made from microfiltered milk, Lait 77 (1997) 521541.

[37] Saboya L.V., Goudedranche H., Maubois J.L., Lerayer A.L.S., Lortal S., Impact of broken cells of lactococci or propionibacteria on the ripening of Saint-Paulin UF-cheeses: extent of proteolysis and GC-MS profiles, Lait 81 (2001) 699-713.

[38] Salvat-Brunaud D., Maubois J.-L., Le Graët Y., Maillard M.B., Corre C., Thierry A., Extraction et analyse de la phase aqueuse de l'emmental à quatre stades d'affinage, Lait 75 (1995) 239-249.

[39] Shalabi S.I., Fox P.F., Electrophoretic analysis of cheese : comparison of methods, Irish J. Food Sci. Technol. 11 (1987) 135151.

[40] Thierry A., Maillard M.B., Le Quéré J.L., Dynamic headspace analysis of Emmental aqueous phase as a method to quantify changes in volatile flavour compounds during ripening, Int. Dairy J. 9 (1999) 453-463.

[41] Thierry A., Maillard M.B., Richoux R., Lortal S., Ethyl ester formation is enhanced by ethanol addition in mini Swiss cheese with and without added propionibacteria, J. Agric. Food Chem. 54 (2006) 6819-6824.

[42] Thomas T.D., Acetate production from lactate and citrate by non starter acid bacteria in Cheddar cheese., N. Z. J. Dairy Sci. Technol. 22 (1987) 25-38.

[43] Upadhyay V.K., McSweeney P.L.H., Magboul A.A.A., Fox P.F., Proteolysis in cheese during ripening, in: Fox P.F., McSweeney P.L.H., Cogan T.M., Guinee T.P. (Eds.), Cheese: Chemistry, Physics and Microbiology, 1, Elsevier, London, 2004, pp. 391-433.

[44] Urbach G.E., Relations between cheese flavour and chemical composition, Int. Dairy J. 3 (1993) 389-422. 